\title{
Chemical and Photochemical Properties of a Ruthenium Nitrosyl Complex with the $N$-Monosubstituted Cyclam 1-(3-Propylammonium)-1,4,8,11- tetraazacyclotetradecane
}

\author{
Kleber Q. Ferreira ${ }^{a, b}$ and Elia Tfouni ${ }^{*, a}$ \\ ${ }^{a}$ Departamento de Química, Faculdade de Filosofia, Ciências e Letras de Ribeirão Preto, \\ Universidade de São Paulo - USP, Av. Bandeirantes, 3900, 14040-901 Ribeirão Preto-SP, Brazil \\ ${ }^{b}$ Departamento de Química Geral e Inorgânica, Instituto de Química, Universidade Federal da \\ Bahia, Rua Barão de Jeremoabo, s/n, Campus Universitário de Ondina, \\ 40170-115 Salvador-BA, Brazil
}

\begin{abstract}
$\mathrm{O}$ complexo aminofuncionalizado trans- $[\mathrm{Ru}(\mathrm{NO}) \mathrm{Cl}(1-$ pramcyH $)]\left(\mathrm{PF}_{6}\right)_{3}(1-$ pramcyH $=$ 1-(3-propilamônio)-1,4,8,11-tetraazaciclotetradecano) foi sintetizado através da reação do trans$[\mathrm{RuCl}(\mathrm{tfms})(1-$ pramcyH$)](\mathrm{tfms})_{2}(\mathrm{tfms}=$ trifluorometanossulfonato $)$ com óxido nítrico $(\mathrm{NO}) \mathrm{em}$ solução aquosa ácida. O complexo foi caracterizado por análise elementar, espectroscópica (UVvis, IV, RMN de $\left.{ }^{1} \mathrm{H} \mathrm{e}^{13} \mathrm{C}\right)$ e eletroquímica. Dois valores de $\mathrm{pK}_{\mathrm{a}}(7,0$ e 8,2) foram determinados para trans- $[\mathrm{Ru}(\mathrm{NO}) \mathrm{Cl}(1-$ pramcyH $)]\left(\mathrm{PF}_{6}\right)_{3}$ e foram atribuídos a um dos prótons do grupo amina do cyclam e ao propilamônio. A redução do trans- $\left[\mathrm{Ru}(\mathrm{NO}) \mathrm{Cl}(1 \text {-pramcyH) }]^{3+}\right.$ leva à saída rápida de cloreto seguida de saída lenta de $\mathrm{NO}$, enquanto a irradiação do complexo em solução aquosa desaerada resulta na labilização fotoquímica do NO. O rendimento quântico para a fotoaquação do NO diminui com o aumento do comprimento de onda de irradiação e com a diminuição do $\mathrm{pH}$, e é observável apenas a $\lambda_{\text {irr }}<370 \mathrm{~nm}$. O comportamento do trans-[Ru(NO)Cl(1-pramcyH) $]^{3+}$ é semelhante ao do complexo análogo trans- $[\mathrm{Ru}(\mathrm{NO}) \mathrm{Cl}(\text { cyclam })]^{2+}$, porém difere daquele do complexo com carboxipropil como substituinte.
\end{abstract}

The amine-functionalized trans- $[\mathrm{Ru}(\mathrm{NO}) \mathrm{Cl}(1-$ pramcyH $)]\left(\mathrm{PF}_{6}\right)_{3}$ complex $(1$-pramcyH $=$ 1-(3-propylammonium)-1,4,8,11-tetraazacyclotetradecane) was synthesized from trans-[RuCl(tfms) $(1$-pramcyH $)](\mathrm{tfms})_{2}(\mathrm{tfms}=$ trifluoromethanesulfonate $)$ in acidic aqueous solution in the presence of nitric oxide (NO). The complex was characterized by elemental, spectroscopic (UV-Vis, IR, ${ }^{1} \mathrm{H}$ and ${ }^{13} \mathrm{C}$ NMR) and electrochemical analyses. Two $\mathrm{pK}_{\mathrm{a}}$ values (7.0 and 8.2) were estimated for trans-[Ru(NO)Cl(1-pramcyH) $]\left(\mathrm{PF}_{6}\right)_{3}$ and were assigned to one of the cyclam nitrogen protons and to the protonated aminopropyl group. Reduction of trans- $[\mathrm{Ru}(\mathrm{NO}) \mathrm{Cl}(1-\mathrm{pramcyH})]^{3+}$ results in rapid loss of chloride followed by slower loss of NO, while irradiation of the complex in aqueous deaerated conditions suggests photochemical labilization of NO. The quantum yields for NO photoaquation decrease as the irradiation wavelength increases, being noticeable only at $\lambda_{\text {irr }}<370 \mathrm{~nm}$, and increase as $\mathrm{pH}$ increases. The behavior of trans- $[\mathrm{Ru}(\mathrm{NO}) \mathrm{Cl}(1-\operatorname{pramcyH})]^{3+}$, which contains an aminopropyl substituted cyclam, parallels that reported for the analogous complex with the unsubstituted ligand, but differs from that described for the complex in which carboxypropyl is the substituent.

Keywords: nitrosyl, ruthenium, nitric oxide donor, substituted cylam, mono- $N$-functionalized cyclam

\section{Introduction}

The discovery of the participation of nitric oxide (NO) in a wide range of physiological processes and pathologies ${ }^{1}$ has launched investigations on NO donors, including metal

*e-mail: eltfouni@usp.br nitrosyl complexes in solution or immobilized in matrices, aiming at the understanding of both fundamental aspects and biological activity for potential applications..$^{2-43}$

Among the NO donors, ruthenium nitrosyl complexes are particularly attractive because they are stable, can be either water soluble or not, deliver NO at different rates upon activation by reduction at biologically accessible 
potentials and/or by light irradiation, in either solution or matrices. ${ }^{14-18,34,40-49}$ These properties can be tuned by the adequate choice of ligands..$^{14,18}$

It should be pointed out that interesting biological activities for several of these complexes have already been reported..$^{14,17,21,33,34,37-39}$ Because NO can be either beneficial or harmful depending on its bioavailability, compounds capable of releasing $\mathrm{NO}$ in a specific biological target have potential biological applications and could be useful tools to study the physiological action of NO. Efforts from this laboratory have been directed toward this goal, using several strategies. One of such approaches involves the functionalization of ruthenium nitrosyl complexes, so they can be linked to important entities such as antibodies and to surfaces, in order to obtain selective NO donor drugs or devices.

We have been working with complexes such as trans$\left[\mathrm{Ru}(\mathrm{NO})\left(\mathrm{NH}_{3}\right)_{4}(\mathrm{py}-\mathrm{X})\right]^{\mathrm{nt}}$ (py-X are pyridine, substituted pyridines, pyrazine), trans- $\left[\mathrm{Ru}(\mathrm{NO}) \mathrm{X}(\mathrm{py}-\mathrm{X})_{4}\right]^{\mathrm{n}+}\left(\mathrm{X}=\mathrm{Cl}^{-}\right.$, $\mathrm{OH}^{-}, \mathrm{H}_{2} \mathrm{O}, \mathrm{NO}_{2}^{-}$, etc. $)$, and $[\mathrm{Ru}(\mathrm{NO}) \mathrm{X}(\mathrm{mac})]^{\mathrm{nt}}\left(\mathrm{X}=\mathrm{Cl}^{-}\right.$, $\mathrm{OH}^{-}, \mathrm{H}_{2} \mathrm{O}$, etc.; mac $=$ tetraazamacrocycle). ${ }^{14,18,41,45}$ The tetraazamacrocyclic $\mathrm{Ru}^{\mathrm{II}}$ and $\mathrm{Ru}^{\mathrm{III}}$ complexes exhibit some unusual features compared to alicyclic analogues. ${ }^{18}$ One of their fundamental properties is the size of the macrocyclic ring. A change in ring size has been shown to markedly affect the electronic spectra, redox potentials, and reactivities of the complexes. ${ }^{18}$ Substitution in the ligand may also affect some properties, such as reactivity.

We have reported the syntheses and reactivity of trans- $[\mathrm{RuCl}(\mathrm{L})(1-\text { pramcyH })]^{n+}(1-$ pramcyH $=$ 1-(3-propylammonium)cyclam), $\mathrm{L}=\mathrm{Cl}^{-}, \mathrm{H}_{2} \mathrm{O}, \mathrm{OH}^{-}$and tfms (trifluoromethanesulfonate), where cyclam has a pendant ammonium group. ${ }^{48}$ The loss of chloride from trans- $\left[\mathrm{RuCl}_{2}(1-\text { pramcyH})\right]^{2+}$ and trans- $\left[\mathrm{RuCl}_{2}(\mathrm{tmc})\right]^{+}(\mathrm{tmc}$ $=$ tetramethylcyclam) is faster than that in the corresponding dichloro cyclam complex. ${ }^{18}$ However, in very few cases, the substitution in the cyclam ligand imparts a drastic shift from the expected properties of the metal complex. ${ }^{19,50,51}$

These complexes present interesting configurations by exhibiting a $\kappa^{3}$ denticity for the mono- $N$-substituted 1-(carboxypropyl)cyclam ligand in $\mathrm{fac}-\left[\mathrm{Ru}(\mathrm{NO}) \mathrm{Cl}_{2}\right.$ $\left(\kappa^{3} N^{4}, N^{8}, N^{11}(1\right.$-carboxypropyl)cyclam) $] \mathrm{Cl} \cdot \mathrm{H}_{2} \mathrm{O},{ }^{19} \kappa^{5}$ for the mono- $N$-substituted $N$-(2-methylpyridyl)cyclam ligand in $c i s-[\mathrm{Ru}(\mathrm{Lpy}) \mathrm{NO}]^{3+}(\mathrm{Lpy}=N-(2-$ methylpyridyl $)-$ 1,4,8,11-tetraazacyclotetradecane),,$^{50}$ and $\kappa^{6}$ for the tetra- $N$-substituted 1,4,8,11-tetrakis(2-pyridylmethyl) cyclam in $[\mathrm{Ru}(\mathrm{HL})]\left[\mathrm{ClO}_{4}\right]_{3} \cdot \mathrm{H}_{2} \mathrm{O}(\mathrm{L}=1,4,8,11$-tetrakis $(2$ pyridylmethyl)cyclam) ${ }^{51}{ }^{5}$ However, when the substituent is ammoniumpropyl (1-(3-propylammonium)cyclam), the ruthenium complex adopts the expected trans configuration in trans- $[\mathrm{RuCl}(\mathrm{L})(1-\text { pramcyH })]^{n+}\left(\mathrm{L}=\mathrm{Cl}^{-}, \mathrm{H}_{2} \mathrm{O}, \mathrm{OH}^{-}\right)$
(trans-[Ru(NO)Cl(1-pramcyH) $\left.]^{3+}\right),{ }^{48}$ instead of the $f a c$ configuration adopted in $f a c$ - $\left[\mathrm{Ru}(\mathrm{NO}) \mathrm{Cl}_{2}\left(\kappa^{3} N^{4}, N^{8}, N^{11}(1-\right.\right.$ carboxypropyl)cyclam) $] \mathrm{Cl} \cdot \mathrm{H}_{2} \mathrm{O}$ when the substituent is carboxypropyl.

In order to verify the effect of the ammoniumpropyl substituent on the configuration of the nitrosyl complex, so as to obtain a wider variety of NO donors, in this paper we report the synthesis, characterization, electrochemical and photochemical properties of the trans- $[\mathrm{Ru}(\mathrm{NO}) \mathrm{Cl}(1-$ pramcyH)]($\left(\mathrm{PF}_{6}\right)_{3}$ complex.

\section{Experimental}

\section{Chemicals and reagents}

Ruthenium trichloride $\left(\mathrm{RuCl}_{3} \cdot \mathrm{nH}_{2} \mathrm{O}\right)(\mathrm{Strem} ; 40-45 \%$ $\mathrm{Ru}$ ) was the starting material for the syntheses of the ruthenium complexes. Cyclam was purchased from Aldrich. Acetone, chloroform and ethanol were purified according to literature procedures. ${ }^{52}$ Doubly distilled water was used throughout this work. All other materials were reagent grade and were used without further purification.

\section{Syntheses}

The trans-[Ru(NO)Cl(cyclam) $]\left(\mathrm{PF}_{6}\right)_{2}$ complex $^{25}$ was synthesized for comparison purposes. ${ }^{1} \mathrm{H}$ NMR (acetonitrile- $\left.d_{3}\right) \delta 1.59\left(\mathrm{~m}, 4 \mathrm{H}, \mathrm{CH}_{2}\right), 1.94(\mathrm{~d}, J 6.8 \mathrm{~Hz}, 2$ $\left.\mathrm{H}, \mathrm{CH}_{2}\right), 2.16\left(\mathrm{~d}, 2 \mathrm{H}, J 5.6 \mathrm{~Hz}, \mathrm{CH}_{2}\right), 2.61\left(\mathrm{~m}, 4 \mathrm{H}, \mathrm{CH}_{2}\right)$, $2.86\left(\mathrm{q}, J 5.4 \mathrm{~Hz}, 2 \mathrm{H}, \mathrm{CH}_{2}\right), 3.09$ (d, J $7.2 \mathrm{~Hz}, 2 \mathrm{H}, \mathrm{CH}_{2}$ ), $3.32\left(\mathrm{~m}, 4 \mathrm{H}, \mathrm{CH}_{2}\right), 5.12(\mathrm{~s}, 2 \mathrm{H}, \mathrm{NH}), 5.66(\mathrm{~s}, 2 \mathrm{H}, \mathrm{NH}) .{ }^{13} \mathrm{C}$ NMR (acetonitrile- $\left.d_{3}\right) \delta 26.66\left(\mathrm{CH}_{2}\right), 28.83\left(\mathrm{CH}_{2}\right), 49.76$ $\left.\left(\mathrm{CH}_{2}\right), 52.42\left(\mathrm{CH}_{2}\right), 52.93\left(\mathrm{CH}_{2}\right), 55.07\left(\mathrm{CH}_{2}\right)\right)$. Trans$\left[\mathrm{RuCl}_{2}(1\right.$-pramcyH $) \mathrm{Cl}_{2},{ }^{48}$ trans-[RuCl(tfms)(1-pramcyH)] $(\mathrm{tfms})_{2}{ }^{48}$ trans- $\left[\mathrm{RuCl}\left(\mathrm{H}_{2} \mathrm{O}\right)(1-\right.$ pramcyH $\left.)\right]\left(\mathrm{PF}_{6}\right)_{3}{ }^{48}$ and trans$\left[\mathrm{RuCl}\left(\mathrm{H}_{2} \mathrm{O}\right)(\mathrm{cyclam})\right]\left(\mathrm{PF}_{6}\right)_{2}{ }^{48}$ complexes were prepared as described elsewhere.

Trans- $[\mathrm{Ru}(\mathrm{NO}) \mathrm{Cl}(1-$ pramcyH $)]\left(\mathrm{PF}_{6}\right)_{3}$ was prepared by a slight modification of a procedure previously described for the synthesis of trans-[Ru(NO)Cl(cyclam) $]\left(\mathrm{PF}_{6}\right)_{2 .}{ }_{25}$ An amount of $77 \mathrm{mg}(0.10 \mathrm{mmol})$ of trans-[RuCl$(\mathrm{tfms})$ (1-pramcyH)](tfms) $)_{2}$ was dissolved in $10 \mathrm{~mL}$ of $0.1 \mathrm{~mol} \mathrm{~L}^{-1}$ $\mathrm{HPF}_{6}$ solution in a three-necked flask under argon atmosphere and continuous stirring. Nitric oxide, which was generated by dropping $30 \%$ nitric acid onto $\mathrm{Cu}$ and passing it through a $6 \mathrm{~mol} \mathrm{~L}^{-1}$ solution of $\mathrm{NaOH}$, was bubbled through the solution. After $4 \mathrm{~h}$ of bubbling, $1 \mathrm{~mL}$ of a saturated aqueous solution of $\mathrm{NH}_{4}\left(\mathrm{PF}_{6}\right)$ was added, and the solution was concentrated to $c a$. $2 \mathrm{~mL}$ by rotary evaporation under reduced pressure. On cooling, the bright yellow solid, that slowly precipitated, was collected by filtration, 
washed with acetone, ether, and dried under vacuum. Yield: $45 \%$ ( $0.17 \mathrm{~g}$; $0.046 \mathrm{mmol})$. Elemental analyses: Found: C, 17.98; H, 3.67; N, 9.65. Calc. for $\mathrm{C}_{13} \mathrm{H}_{32} \mathrm{ClF}_{18} \mathrm{~N}_{6} \mathrm{OP}_{3} \mathrm{Ru}$ : $\mathrm{C}, 18.16 ; \mathrm{H}, 3.75 ; \mathrm{N}, 9.77 \%$. UV-Vis $\lambda_{\max } / \mathrm{nm}$ (water) $272\left(\varepsilon /\left(\mathrm{dm}^{3} \mathrm{~mol}^{-1} \mathrm{~cm}^{-1}\right) 3.1 \times 10^{3}\right), 360\left(4 \times 10^{2}\right)$ and 455 (90). ${ }^{1} \mathrm{H}$ NMR (acetonitrile- $\left.d_{3}\right) \delta 1.86\left(\mathrm{~m}, 3 \mathrm{H}, \mathrm{CH}_{2}\right)$, $2.15\left(\mathrm{~m}, 3 \mathrm{H}, \mathrm{CH}_{2}\right), 2.66\left(\mathrm{~m}, 5 \mathrm{H}, \mathrm{CH}_{2}\right), 2.78(\mathrm{~m}, 4 \mathrm{H}$, $\mathrm{CH}_{2}$ ), $3.07\left(\mathrm{t}, J 4.5 \mathrm{~Hz}, 2 \mathrm{H}, \mathrm{CH}_{2}\right), 3.29(\mathrm{~d}, J 4.8 \mathrm{~Hz}, 3 \mathrm{H}$, $\left.\mathrm{CH}_{2}\right), 3.45\left(\mathrm{~d}, J 5.2 \mathrm{~Hz}, 2 \mathrm{H}, \mathrm{CH}_{2}\right), 3.55(\mathrm{dd}, J 5.3 \mathrm{~Hz}, 4 \mathrm{H}$, $\left.\mathrm{CH}_{2}\right), 5.36(\mathrm{~s}, 3 \mathrm{H}, \mathrm{NH}), 6.06(\mathrm{~s}, 1 \mathrm{H}, \mathrm{NH}), 6.26(\mathrm{~s}, 2 \mathrm{H}$, $\mathrm{NH}) .{ }^{13} \mathrm{C}$ NMR (acetonitrile- $\left.d_{3}\right) \delta 29.89\left(\mathrm{CH}_{2}\right), 30.05\left(\mathrm{CH}_{2}\right)$, $30.23\left(\mathrm{CH}_{2}\right), 50.48\left(\mathrm{CH}_{2}\right), 51.20\left(\mathrm{CH}_{2}\right), 53.27\left(\mathrm{CH}_{2}\right), 53.50$ $\left(\mathrm{CH}_{2}\right), 53.82\left(\mathrm{CH}_{2}\right), 54.39\left(\mathrm{CH}_{2}\right), 55.20\left(\mathrm{CH}_{2}\right), 55.80\left(\mathrm{CH}_{2}\right)$, $56.10\left(\mathrm{CH}_{2}\right), 56.54\left(\mathrm{CH}_{2}\right)$.

\section{Elemental analyses}

Analyses were performed at the Departamento de Química, Faculdade de Filosofia, Ciências e Letras de Ribeirão Preto, University of São Paulo, using an Elemental Analyzer CE Instruments, model EA 1110.

\section{Spectra}

Electronic absorption spectra were recorded on a Hewlett-Packard model 8452A spectrophotometer using quartz cells. Infrared absorption spectra were obtained in Nujol mulls, in water or in acetonitrile, on a Bomen MB-102 spectrophotometer. ${ }^{1} \mathrm{H}$ and ${ }^{13} \mathrm{C}$ NMR spectra were obtained in $5 \mathrm{~mm}$ NMR tubes on a Bruker WH400 spectrometer in acetonitrile- $d_{3}$ or $\mathrm{D}_{2} \mathrm{O}$. The EPR experiments were conducted in frozen acetonitrile $(77 \mathrm{~K})$ in an ESP-300E Bruker instrument operated with an X-band microwave bridge.

\section{Electrochemical measurements}

Cyclic voltammetry and controlled potential electrolysis were performed with a PARC 273 potentiostat/galvanostat. All tests were carried out using a conventional threeelectrode cell. Glassy carbon and platinum gauze were used as working electrodes for cyclic voltammetry and coulometry, respectively. $\mathrm{Ag} / \mathrm{AgCl}$ and platinum wire were used as the reference and auxiliary electrodes respectively. Electrochemical data were obtained in different media, as follows: $\mathrm{pH} 1\left(\mathrm{CF}_{3} \mathrm{SO}_{3} \mathrm{H} / \mathrm{CF}_{3} \mathrm{SO}_{3} \mathrm{Na}\right.$, $\mu=0.1 \mathrm{~mol} \mathrm{~L}-1) ; \mathrm{pH} 4.32\left(\mathrm{CF}_{3} \mathrm{COOH} / \mathrm{CF}_{3} \mathrm{COONa}\right.$, $\left.\mu=0.1 \mathrm{~mol} \mathrm{~L}^{-1}\right) ; \mathrm{pH} 1\left(\mathrm{HCl} / \mathrm{KCl}, \mu=0.1 \mathrm{~mol} \mathrm{~L}^{-1}\right) ; \mathrm{pH} 7.9$ $\left(\mathrm{NaH}_{2} \mathrm{PO}_{4} \cdot \mathrm{H}_{2} \mathrm{O} / \mathrm{Na}_{2} \mathrm{HPO}_{4}, \mu=0.1 \mathrm{~mol} \mathrm{~L}-1\right) ; \mathrm{pH} 6(\mathrm{LiCl}$, $\mu=0.2 \mathrm{~mol} \mathrm{~L}^{-1}$ ); and acetonitrile, $\mu=0.1 \mathrm{~mol} \mathrm{~L}^{-1}$, containing tetrabutylammonium hexafluorophosphate $\left[\mathrm{tba}\left(\mathrm{PF}_{6}\right)\right]$. All solutions were deaerated by bubbling high purity argon, and thermostated using a Haake FK ultracryostat. The reported $\mathrm{E}_{1 / 2}$ ' values are the arithmetic means of the $\mathrm{E}_{\mathrm{pa}}$ and $\mathrm{E}_{\mathrm{pc}}$ values.

The spectroelectrochemical measurements in the UV-Vis region were carried out in a quartz cell with $0.030 \mathrm{~cm}$ optical path, using gold mini-grid, $\mathrm{Ag} / \mathrm{AgCl}$ and platinum wire as working, reference and auxiliary electrodes respectively. Analogous measurements in the infrared region were carried out using gold mini-grid, Ag wire and gold wire as working, reference and auxiliary electrodes respectively, mounted in a $\mathrm{CaF}_{2}$ window with $0.020 \mathrm{~cm}$ optical path. Successive UV-Vis or IR spectra for trans-[Ru(NO)Cl(cyclam) $]\left(\mathrm{PF}_{6}\right)_{2}$ and trans-[Ru(NO) $\mathrm{Cl}(1$-pramcyH $)]\left(\mathrm{PF}_{6}\right)_{3}$ were recorded during the reduction process of the complexes at $25^{\circ} \mathrm{C}$, with applied potentials of $-500 \mathrm{mV} v s . \mathrm{Ag} / \mathrm{AgCl}$ in acetonitrile solutions. The $\mathrm{pH}$ measurements were performed using a 430 Analion or a Corning pH meters.

\section{Photolyses}

Monochromatic irradiations at 313, 334 and $370 \mathrm{~nm}$ were carried out using a $150 \mathrm{~W}$ Xenon lamp in an Oriel Universal Arc Lamp Source (model 6253). For photolysis at the appropriate wavelengths, the irradiation wavelength was selected with Oriel interference filters, with an average band path of $10 \mathrm{~nm}$.

The progress of the photoreactions was monitored spectrophotometrically on a MB Bomem 102 FTIR spectrophotometer, using a ZnSe ATR crystal, or on an HP8452A diode array spectrophotometer for in-situ vibrational and electronic spectroscopy respectively. For most runs, the initial concentration of the complex was ca. $10^{-2}$ (infrared experiments) to $10^{-3} \mathrm{~mol} \mathrm{~L}^{-1}$ (UV-Vis experiments) in the following buffers: $\mathrm{CF}_{3} \mathrm{SO}_{3} \mathrm{H}_{2} \mathrm{CF}_{3} \mathrm{SO}_{3} \mathrm{Na}$ $\left(\mu=0.1 \mathrm{~mol} \mathrm{~L}^{-1} ; \mathrm{pH} 1\right), \mathrm{CH}_{3} \mathrm{COOH} / \mathrm{CH}_{3} \mathrm{COONa}$ $\left(\mu=0.1 \mathrm{~mol} \mathrm{~L}{ }^{-1} ; \mathrm{pH} 4.75\right) ; \mathrm{CH}_{3} \mathrm{COOH} / \mathrm{CH}_{3} \mathrm{COONa}$ $(\mu=0.1 \mathrm{~mol} \mathrm{~L}-1 ; \mathrm{pH} 4.90)$, or $\mathrm{Na}_{2} \mathrm{HPO}_{4} / \mathrm{NaH}_{2} \mathrm{PO}_{4}$ $\left(\mu=0.1 \mathrm{~mol} \mathrm{~L}^{-1} ; \mathrm{pH} 7.4\right)$. The collimated beam intensities ranged from $1 \times 10^{-9}$ to $4 \times 10^{-8}$ einstein ${ }^{-1} \mathrm{~cm}^{-2}$ as determined by ferrioxalate actinometry. The chemical actinometer potassium tris(oxalato)ferrate(III) was prepared according to Calvert and Pitts. ${ }^{53}$ After the equilibration of the cell holder temperature, photolysis begun by irradiating the sample for a period of time ranging from 0 to $7200 \mathrm{~s}$, with increments of $1200 \mathrm{~s}$.

Considering that the coordinated water of trans$\left[\mathrm{RuCl}(1-\mathrm{pramcyH})\left(\mathrm{OH}_{2}\right)\right]^{3+}$ has a $\mathrm{pK}_{\mathrm{a}}$ of $3.1,{ }^{48}$ the calculated $\mathrm{NO}$ quantum yield was based on the concentrations of the photoproduct trans-[RuCl(1-pramcyH)(L) $]^{\mathrm{nt}}\left(\mathrm{L}=\mathrm{H}_{2} \mathrm{O}\right.$, 
$\mathrm{OH}^{-}$), obtained by spectroscopic determination with absorbance readings at $\lambda=356 \mathrm{~nm}$ for the photolysis at $\mathrm{pH}=1$. At this $\mathrm{pH}$, trans $-\left[\mathrm{RuCl}(1-\text { pramcyH })\left(\mathrm{OH}_{2}\right)\right]^{3+}$ $\left(\lambda_{\max } / \mathrm{nm}=356, \varepsilon /\left(\mathrm{dm}^{3} \mathrm{~mol}^{-1} \mathrm{~cm}^{-1}\right)=2900\right)$ is formed. At pHs 4.75 and 4.90, a mixture of trans-[RuCl(1-pramcyH) $\left.\left(\mathrm{OH}_{2}\right)\right]^{3+}$ and trans- $[\mathrm{RuCl}(1-\text { pramcyH })(\mathrm{OH})]^{2+}\left(\lambda_{\max }=315\right.$, $\varepsilon=830)$ is obtained. At $\mathrm{pH} 7.4$, only trans-[RuCl(1pramcyH $)(\mathrm{OH})]^{2+}\left(\lambda_{\max }=310, \varepsilon=1.0 \times 10^{3}\right)$ is produced.

The calculated $\phi_{\mathrm{NO}}$ values were plotted versus $\%$ of the reaction ( $\phi x \% \mathrm{R})$. The extrapolated spectroscopic quantum yield at $\mathrm{R}=0 \%$ was taken as $\phi_{\mathrm{NO}}$ for the photoaquation of $\mathrm{NO}$ from trans-[Ru(NO)Cl(1-pramcyH) $]^{3+}$. Evaluation of $\phi_{\mathrm{NO}}$ at $\mathrm{R}=0 \%$ eliminates possible complications resulting from secondary photolysis of primary reaction products and inner filter effects.

\section{Results and Discussion}

\section{Syntheses}

The synthesis of the 1-pramcyH complex uses trans$[\mathrm{Ru}(\mathrm{tfms}) \mathrm{Cl}(1$-pramcyH $)](\mathrm{tfms})_{2}$ as precursor, which, in acidic aqueous solution, aquates with a specific rate constant, $k_{1}$, of $6.5 \times 10^{-2} \mathrm{~s}^{-1}$ at $\mathrm{pH} 1$, forming trans$\left[\mathrm{RuCl}\left(\mathrm{OH}_{2}\right)(1-\text { pramcyH})\right]^{3+}$. $^{48}$ As for the cyclam complex, trans $-[\mathrm{Ru}(\mathrm{NO}) \mathrm{Cl}($ cyclam $)]\left(\mathrm{PF}_{6}\right)_{2}$, trans $-\left[\mathrm{RuCl}\left(\mathrm{H}_{2} \mathrm{O}\right)\right.$ (1-pramcyH) $]^{3+}$ generates trans-[Ru(NO)Cl(1-pramcyH) $]^{3+}$ in the presence of NO. The nitrosyl complex was obtained as its hexafluorophosphate salt, trans-[Ru(NO)Cl(1-pramcyH)] $(\mathrm{PF} 6)_{3}$, which is soluble in water, acetonitrile, methanol and dimethylsulfoxide, and in a lesser extent in acetone.

Because the complex was isolated in acidic medium ( $0.1 \mathrm{~mol} \mathrm{~L}^{-1} \mathrm{HPF}_{6}$ ), the aminopropyl group is protonated. Potentiometric titration allowed estimation of two $\mathrm{pK}_{\mathrm{a}}$ values (7.0 and 8.2) for trans-[Ru(NO)Cl(1-pramcyH)] $\left(\mathrm{PF}_{6}\right)_{3}$, which should be ascribed to one of the cyclam nitrogen protons and to the protonated propylammonium. Considering that the cyclam nitrogen of the related complexes trans$[\operatorname{RuCl}(\text { cyclam })(\mathrm{NHC}(\mathrm{O}) 4-\mathrm{py})]^{+}(\mathrm{py}=$ pyridine $)$, trans$\left[\mathrm{RuCl}_{2}(1 \text {-pramcyH })\right]^{2+}$, and trans- $[\mathrm{RuCl}(\mathrm{OH})(1 \text {-pramcyH })]^{2+}$ have $\mathrm{pK}_{\mathrm{a}}$ values of 7.9, 8.0, and 7.8, respectively, ${ }^{48,54}$ and free propylammonium has a $\mathrm{pK}_{\mathrm{a}}$ of $9.8,55,56$ it is difficult to undoubtedly assign the $\mathrm{pK}_{\mathrm{a}}$ values. However, it is more likely that the $\mathrm{pK}_{\mathrm{a}}$ of 7.0 refers to the cyclam nitrogen and that of 8.2 to propylammonium, value that is lower than 9.8 due to the charge effect of the Ru metal center, as expected.

\section{$I R, E P R, N M R$ and electronic spectra}

In nitrosyl complexes, an IR absorption band assigned to NO stretching in the $1950-1800 \mathrm{~cm}^{-1}$ region is associated with a linear structure for $\mathrm{Ru}-\mathrm{N}-\mathrm{O}$ and a nitrosonium character $\left(\mathrm{NO}^{+}\right){ }^{57}$ Ruthenium complexes of this type are often represented by the resonance form $\mathrm{Ru}^{\mathrm{II}}\left(\mathrm{NO}^{+}\right)$. As pointed out earlier, this formulation is one of several resonance forms (others being $\mathrm{Ru}^{\mathrm{III}}(\mathrm{NO})$ and $\mathrm{Ru}^{\mathrm{IV}}\left(\mathrm{NO}^{-}\right)$), and, following Enemark and Feltham's ${ }^{58}$ notation, the $\{\mathrm{Ru}-\mathrm{NO}\}^{6}$ complexes are highly delocalized. The IR spectrum of nujol mulls of trans-[Ru(NO)Cl(1-pramcyH)] $\left(\mathrm{PF}_{6}\right)_{3}$ displays three peaks at $1880 \mathrm{~cm}^{-1}, 1865 \mathrm{~cm}^{-1}$ and $1842 \mathrm{~cm}^{-1}$ (Figure 1). In the IR spectra of ruthenium nitrosyl complexes recorded from Nujol mulls or $\mathrm{KBr}$ pellets, the NO stretching band sometimes appears as two or more peaks or as one peak with one or two shoulders. This feature has been assigned to solid state effects. ${ }^{18}$ However, only one peak at $1875 \mathrm{~cm}^{-1}$ appears in the spectrum of the aqueous solution of trans-[Ru(NO)Cl(1-pramcyH)] $\left(\mathrm{PF}_{6}\right)_{3}$; it is shifted to $1864 \mathrm{~cm}^{-1}$ in acetonitrile (Figure 2), indicating a solvent dependence for the $v(\mathrm{NO})$. These peaks support the nitrosonium character of NO in this complex. An attempt to obtain an EPR spectrum for trans-[Ru(NO) $\mathrm{Cl}(1$-pramcyH $)]\left(\mathrm{PF}_{6}\right)_{3}$ showed no signal, giving further support to the IR assignment.

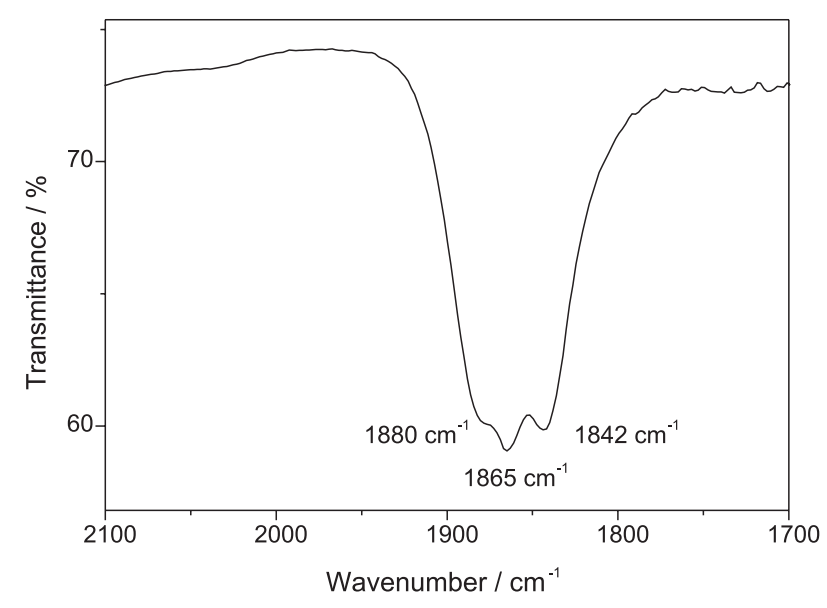

Figure 1. Infrared spectrum of trans-[Ru(NO)Cl(1-pramcyH) $]\left(\mathrm{PF}_{6}\right)_{3}$ in nujol mull.

The ${ }^{1} \mathrm{H}$ and ${ }^{13} \mathrm{C}$ NMR spectra of trans-[Ru(NO)Cl (1-pramcyH) $]\left(\mathrm{PF}_{6}\right)_{3}$ are consistent with the presence of the 3-propylammonium group $\left(-\left(\mathrm{CH}_{2}\right)_{3} \mathrm{NH}_{3}^{+}\right)$bound to a cyclam nitrogen. The ${ }^{1} \mathrm{H}$ NMR chemical shifts in the 5-7.5 ppm range can be assigned to the hydrogen atoms linked to the nitrogens of cyclam and those of the 3-propylammonium group (Figure S1 in Supplementary Information).

In the already described ${ }^{1} \mathrm{H}$ NMR spectrum of trans- $[\mathrm{Ru}(\mathrm{NO}) \mathrm{Cl}($ cyclam $)]\left(\mathrm{PF}_{6}\right)_{2}$ obtained in $\mathrm{D}_{2} \mathrm{O},{ }^{25}$ the NH's hydrogen signals are absent because of fast H-D exchange. ${ }^{18,60}$ Hence, the ${ }^{1} \mathrm{H}$ NMR spectrum of trans$[\mathrm{Ru}(\mathrm{NO}) \mathrm{Cl}(\mathrm{cyclam})]\left(\mathrm{PF}_{6}\right)_{2}$ was obtained in acetonitrile- $d_{3}$ 


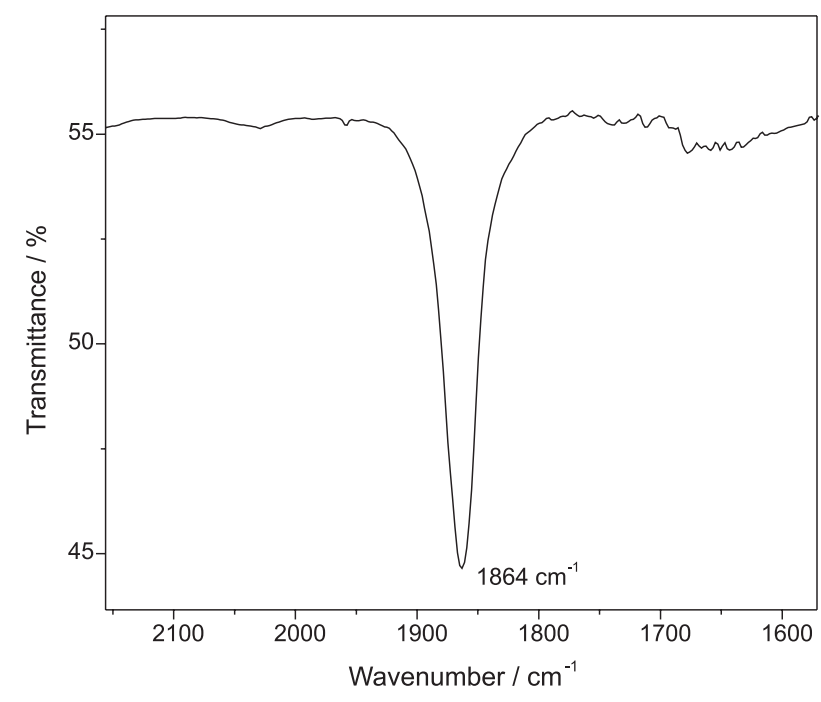

Figure 2. Infrared spectrum of a $10^{-2} \mathrm{~mol} \mathrm{~L}^{-1}$ acetonitrile solution of trans-[Ru(NO)Cl(1-pramcyH $)]\left(\mathrm{PF}_{6}\right)_{3}$.

for comparison, and it has a relatively simple resonance pattern regarding the $\mathrm{NH}$-cyclam hydrogens, as a result of the higher symmetry of the cyclam moiety in this geometry. ${ }^{25}$ There are two signals in the 5-7.5 ppm range $(\delta=5.12$ and $5.66 \mathrm{ppm})$ (see Experimental section), with 2:2 intensities, assigned to four NH hydrogens of cyclam. In its turn, the ${ }^{1} \mathrm{H} N M R$ spectrum of trans- $[\mathrm{Ru}(\mathrm{NO}) \mathrm{Cl}(1-$ pramcyH $)]\left(\mathrm{PF}_{6}\right)_{3}$ in acetonitrile- $d_{3}$ shows three signals of NH hydrogens with 3:1:2 intensities (Figure S1). The signal with $\delta 5.36 \mathrm{ppm}$ was assigned to the hydrogen atoms linked to the nitrogen of 3-propylammonium group, while the signals with $\delta 6.06$ and $\delta 6.26 \mathrm{ppm}$ were assigned to hydrogen atoms linked to the cyclam nitrogens. These signals were absent in the ${ }^{1} \mathrm{H}$ NMR in $\mathrm{D}_{2} \mathrm{O}$ because of fast $\mathrm{H}-\mathrm{D}$ exchange. The integral of the signals assigned to the carbon chain hydrogens of the 1-(3-propylammonium) cyclam ligand is consistent with 26 hydrogens in this molecule (see Experimental section).

The ${ }^{13} \mathrm{C}$ NMR spectrum of trans-[Ru(NO)Cl(cyclam)] $\left(\mathrm{PF}_{6}\right)_{2}$ in acetonitrile- $d_{3}$ displays six signals in the 26-56 ppm range assigned to the $\mathrm{CH}_{2}$ aliphatic carbons present in the macrocyclic ligand, and is consistent with that of trans-[RuCl(cyclam)(4-acpy) $]\left(\mathrm{BF}_{4}\right)_{2} \cdot{ }^{59}$ In its turn, the ${ }^{13} \mathrm{C}$ NMR spectrum of trans- $[\mathrm{Ru}(\mathrm{NO})$ $\mathrm{Cl}(1$-pramcyH $)]\left(\mathrm{PF}_{6}\right)_{3}$ in acetonitrile- $d_{3}$ shows thirteen peaks (Figure S2), assigned to the $\mathrm{CH}_{2}$ aliphatic carbons present in the 1-(3-propylammonium)cyclam ligand. The structure of this complex in solution is shown in Figure 3, and is similar to those of trans-[Ru(NO)Cl(cyclam)] $\left(\mathrm{PF}_{6}\right)_{2},{ }^{25}$ trans $-[\mathrm{RuCl}(\mathrm{cyclam})(4-\mathrm{acpy})]\left(\mathrm{BF}_{4}\right)_{2}, 59$ and trans-[ $\mathrm{RuCl}_{2}$ (cyclam)]Br. ${ }^{61}$ This trans configuration is the thermodinamically expected one, unlike that of fac$\left[\mathrm{Ru}(\mathrm{NO}) \mathrm{Cl}_{2}\left(\kappa^{3} N^{4}, N^{8}, N^{11}(1 \text {-carboxypropyl)cyclam })\right]^{+}\right.$, a very closely related cyclam monosubstituted complex, where the cyclam ring $\mathrm{N}$ (with the carboxypropyl pendant arm instead of an aminopropyl) is not coordinated to the ruthenium, resulting in $\kappa^{3}$ denticity. ${ }^{19}$

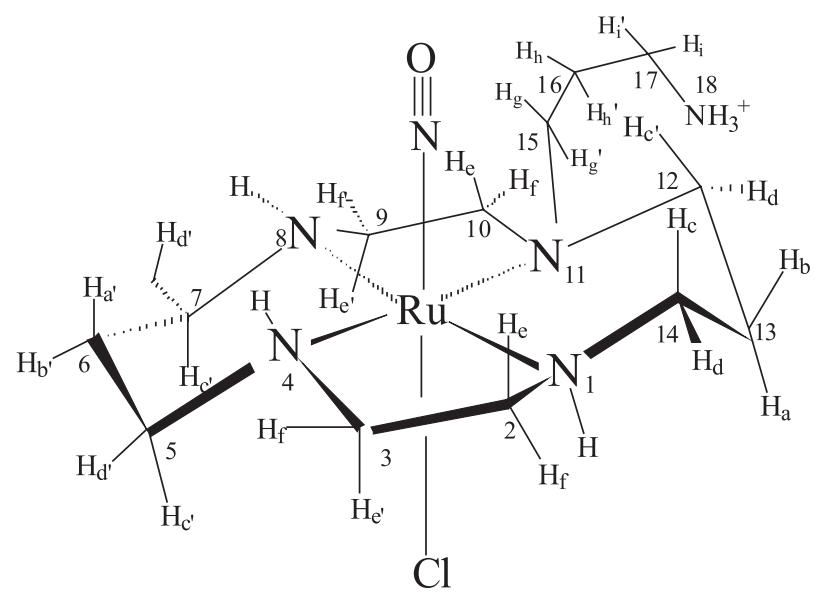

Figure 3. Structure of trans-[Ru(NO)Cl(1-pramcyH) $]^{3+}$.

The electronic spectrum of trans-[Ru(NO)Cl(1pramcyH) $]^{3+}$ (Figures S3 and S4) is similar to those of other ruthenium nitrosyl complexes, ${ }^{17,18,25}$ especially that of the related cyclam complex, trans-[Ru(NO) $\mathrm{Cl}($ cyclam $)]^{3+}$, as expected. This is due to the similarity of the ligands and, therefore, the bands were assigned by analogy. The spectrum of a $\mathrm{pH} 1$ aqueous solution of trans$[\mathrm{Ru}(\mathrm{NO}) \mathrm{Cl}(1-\text { pramcyH})]^{3+}$ displays one band at $272 \mathrm{~nm}$ $\left(\varepsilon /\left(\mathrm{dm}^{3} \mathrm{~mol}^{-1} \mathrm{~cm}^{-1}\right)=3.1 \times 10^{3}\right)$, ascribed to a ligand to metal charge transfer $(\mathrm{LMCT})\left[\mathrm{p}_{\pi}(\mathrm{Cl}) \rightarrow \mathrm{e}_{\mathrm{g}}(\mathrm{Ru})\right]$, and another band at $360 \mathrm{~nm}\left(\varepsilon=4 \times 10^{2}\right)$ assigned to at least a spin-allowed $\mathrm{d}-\mathrm{d}$ transition plus an additional contribution from a metal to ligand charge transfer (MLCT) due to a $\mathrm{d}_{\pi}(\mathrm{Ru}) \rightarrow \pi^{*}(\mathrm{NO})$ transition. The band at $455 \mathrm{~nm}(\varepsilon=90)$ was assigned to a ligand field transition with a possible contribution from another $\mathrm{d}_{\pi}(\mathrm{Ru}) \rightarrow \pi^{*}(\mathrm{NO})$ MLCT transition.

\section{Redox potentials}

The cyclic voltammetry study of trans-[Ru(NO) $\mathrm{Cl}(1$-pramcyH $)]\left(\mathrm{PF}_{6}\right)_{3}$ in acetonitrile $\left[25^{\circ} \mathrm{C} ; 100 \mathrm{mV} \mathrm{s}^{-1}\right.$; $\mu=0.1 \mathrm{~mol} \mathrm{~L}^{-1}$ tba $\left.\left(\mathrm{PF}_{6}\right)\right]$ reveals three electrochemical processes in the $-1.6 \mathrm{~V}$ to $+1 \mathrm{~V}$ range $(v s . \mathrm{Ag} / \mathrm{AgCl})$ : $\mathrm{Ep}_{2 \mathrm{c}}=-1350 \mathrm{mV}, \mathrm{Ep}_{\mathrm{lc}}=-320 \mathrm{mV}$ and $\mathrm{Ep}_{\mathrm{la}}=-220 \mathrm{mV}$ (Figure S5). The ratio of the $\mathrm{Ep}_{1 \mathrm{c}}$ and $\mathrm{Ep}_{\mathrm{la}}$ current peak heights approaches unity as the scan rate increases, consistent with a coupled chemical reaction, assigned to the slow loss of $\mathrm{NO}$ following reduction to trans-[Ru(NO)Cl(1pramcyH $)]^{2+}$, similarly to trans-[Ru(NO)Cl(cyclam) $]^{+} \cdot{ }^{25}$ If the $\left[\mathrm{Ru}^{\mathrm{II}}-\mathrm{NO}^{+}\right]$formalism is considered, the $\mathrm{Ep}_{1 \mathrm{c}}$ and $\mathrm{Ep}_{\mathrm{la}}$ processes can be attributed to the $\mathrm{NO}^{+} / \mathrm{NO}^{0}$ ( or $\{\mathrm{RuNO}\}^{6 / 7}$ ) 
$\operatorname{trans}-[\mathrm{RuCl}(\mathrm{NO})(1-\mathrm{pramcyH})]^{3+} \underset{-\mathrm{e} 1 \mathrm{a}}{\stackrel{+\mathrm{e} 1 \mathrm{c}}{\rightleftharpoons}} \operatorname{trans}-[\mathrm{RuCl}(\mathrm{NO})(1-\text { pramcyH})]^{2+}$

trans-[RuCl(NO)(1-pramcyH) $]^{2+} \stackrel{+\mathrm{e} 3 \mathrm{c}}{\underset{-\mathrm{e}}{\rightleftharpoons}} \operatorname{trans}-[\mathrm{RuCl}(\mathrm{NO})(1-\text { pramcyH })]^{+}$

couple by analogy with trans-[Ru(NO)Cl(cyclam) $]^{2+}$, for which $\mathrm{Ep}_{1 \mathrm{c}}=-210 \mathrm{mV}$ and $\mathrm{Ep}_{1 \mathrm{a}}=-150 \mathrm{mV}(v s . \mathrm{Ag} / \mathrm{AgCl})$ were obtained (equation 1 ). The previously reported values of $\mathrm{Ep}_{1 \mathrm{c}}=-262 \mathrm{mV}$ and $\mathrm{Ep}_{1 \mathrm{a}}=-82 \mathrm{mV}(\mathrm{vs} . \mathrm{Ag} / \mathrm{AgCl})^{25}$ were probably due to an ohmic drop. The $\mathrm{Ep}_{2 \mathrm{c}}$ process at $-1.35 \mathrm{~V}$ can be assigned to the $\{\mathrm{RuNO}\}^{7 / 8}$ process, similarly to trans-[Ru(NO)Cl(cyclam) $]^{\text {n+ }}$ (equation 2$) .{ }^{25}$

The cyclic voltammetric behavior of trans $-[\mathrm{Ru}(\mathrm{NO})$ $\mathrm{Cl}(1$-pramcyH $)]\left(\mathrm{PF}_{6}\right)_{3}$ in $0.1 \mathrm{~mol} \mathrm{~L}-1 \mathrm{CF}_{3} \mathrm{SO}_{3} \mathrm{H} / \mathrm{CF}_{3} \mathrm{SO}_{3} \mathrm{Na}$ at $\mathrm{pH} 1$ and $25^{\circ} \mathrm{C}$ is very similar to that of trans-[Ru(NO) $\mathrm{Cl}($ cyclam $)]^{3+} .{ }^{25}$ At a $100 \mathrm{mV} \mathrm{s}^{-1}$ scan rate, there are three electrochemical processes, namely $\mathrm{Ep}_{1 \mathrm{c}}=-390 \mathrm{mV}$, $\mathrm{Ep}_{2 \mathrm{c}}=-530 \mathrm{mV}$, and $\mathrm{Ep}_{2 \mathrm{a}}=-400 \mathrm{mV}$ vs. $\mathrm{Ag} / \mathrm{AgCl}$ (Figure 4). At these conditions, peak 1a (see ahead) is enveloped by peak $2 \mathrm{a}$; peaks $2 \mathrm{c}$ and $2 \mathrm{a}$ are $\mathrm{pH}$ dependent in the 1-9 $\mathrm{pH}$ range, while the others are $\mathrm{pH}$ independent. When the cyclic voltammogram is run in $0.2 \mathrm{~mol} \mathrm{~L}^{-1} \mathrm{LiCl}$ at $\mathrm{pH} 6$ or in $0.1 \mathrm{~mol} \mathrm{~L}^{-1} \mathrm{HCl} / \mathrm{KCl}$ at $\mathrm{pH} 1$, only two peaks are detected, $\mathrm{Ep}_{\mathrm{lc}}$ at $-370 \mathrm{mV}$ and $\mathrm{Ep}_{\mathrm{la}}$ at $-290 \mathrm{mV}$ vs. $\mathrm{Ag} / \mathrm{AgCl}$; peaks $2 \mathrm{a}$ and $2 \mathrm{c}$ are no longer observed (Figure S6). These results are consistent with suppression of the chloride dissociation, and the observed redox process is assigned to the $\{\mathrm{RuNO}\}^{6 / 7}$ couple for trans$[\mathrm{Ru}(\mathrm{NO}) \mathrm{Cl}(1-\text { pramcyH})]^{3+}$ (equation 1).

Reduction of trans-[Ru(NO)Cl(1-pramcyH) $]^{3+}$ at $-400 \mathrm{mV}$ should be followed by a fast chloride release, as verified by a test with silver nitrate, to form trans-[Ru(NO) $\left(\mathrm{OH}_{2}\right)(1-$ pramcyH $\left.)\right]^{3+}$ (equation 3), which then loses NO at a smaller rate, to form trans- $\left[\mathrm{Ru}\left(\mathrm{OH}_{2}\right)_{2}(1-\text { pramcyH })\right]^{3+}$

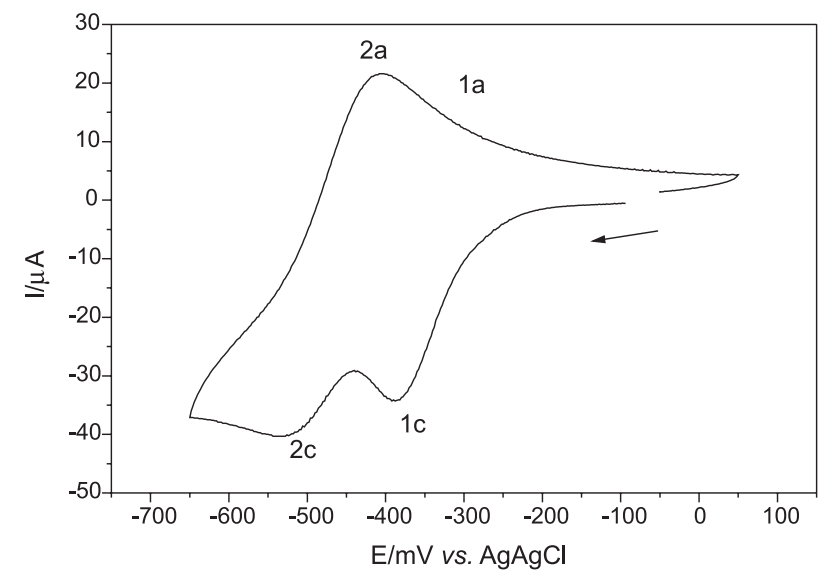

Figure 4. Cyclic voltammogram of a $7 \times 10^{-3} \mathrm{~mol} \mathrm{~L}^{-1}$ solution of trans$[\mathrm{Ru}(\mathrm{NO}) \mathrm{Cl}(1-\mathrm{pramcyH})]\left(\mathrm{PF}_{6}\right)_{3}$. Conditions: $0.1 \mathrm{~mol} \mathrm{~L}^{-1} \mathrm{CF}_{3} \mathrm{SO}_{3} \mathrm{H} /$ $\mathrm{CF}_{3} \mathrm{SO}_{3} \mathrm{Na}$ at $\mathrm{pH} 1 ; 100 \mathrm{mV} \mathrm{s}^{-1}$; glassy carbon, $\mathrm{Ag} / \mathrm{AgCl}$ and platinum wire as the working, reference and auxiliary electrodes, respectively; $\mathrm{T}=25^{\circ} \mathrm{C}$.

(equation 4). The $\mathrm{pH}$ dependent $2 \mathrm{c} / 2 \mathrm{a}$ pair of peaks was attributed to the $\{\mathrm{RuNO}\}^{6 / 7}$ couple in trans-[Ru(NO)(OH$)$ (1-pramcyH) $]^{4+}$ (equation 5), after loss of chloride.

Only when the scan range is extended further to $-1.5 \mathrm{~V}(v s . \mathrm{Ag} / \mathrm{AgCl})$ in $0.1 \mathrm{~mol} \mathrm{~L}^{-1} \mathrm{CF}_{3} \mathrm{SO}_{3} \mathrm{H} / \mathrm{CF}_{3} \mathrm{SO}_{3} \mathrm{Na}$ at $\mathrm{pH} 1$, and the coordinated $\mathrm{NO}^{0}$ undergoes a further reduction process $\left\{\mathrm{RuNO}^{7 / 8}\right.$ (equation 6 ), or at smaller scan rates, is it possible to observe the presence of the trans- $\left[\mathrm{Ru}\left(\mathrm{H}_{2} \mathrm{O}\right)_{2}(1-\text { pramcyH})\right]^{3+}$ species (equation 7) in the repetitive scan mode. The trans- $\left[\mathrm{Ru}\left(\mathrm{H}_{2} \mathrm{O}\right)_{2}(1-\text { pramcyH })\right]^{3+}$ species exhibits a reversible, $\mathrm{pH}$ dependent, one electron electrochemical process at $\mathrm{E}_{1 / 2}=-50 \mathrm{mV}$ close to the

$$
\begin{aligned}
& \text { trans-[RuCl(NO)(1-pramcyH) }]^{2+}+\mathrm{H}_{2} \mathrm{O} \underset{\mathrm{k}_{-1}}{\stackrel{\mathrm{k}_{1}}{\rightleftharpoons}} \text { trans }-\left[\mathrm{Ru}\left(\mathrm{OH}_{2}\right)(\mathrm{NO})(1-\text { pramcyH})\right]^{3+}+\mathrm{Cl}^{-} \\
& \text {trans }-\left[\mathrm{Ru}\left(\mathrm{OH}_{2}\right)(\mathrm{NO})(1-\text { pramcyH})\right]^{3+}+\mathrm{H}_{2} \mathrm{O} \underset{\mathrm{k}_{2}}{\stackrel{\mathrm{k}_{2}}{\rightleftharpoons}} \operatorname{trans}-\left[\mathrm{Ru}\left(\mathrm{OH}_{2}\right)_{2}(1-\text { pramcyH })\right]^{3+}+\mathrm{NO} \\
& \text { trans- }\left[\mathrm{Ru}\left(\mathrm{OH}_{2}\right)(\mathrm{NO})(1-\text { pramcyH })\right]^{4+} \underset{-\mathrm{e} 2 \mathrm{a}}{\stackrel{+\mathrm{e} 2 \mathrm{c}}{\rightleftharpoons}} \operatorname{trans}-\left[\mathrm{Ru}\left(\mathrm{OH}_{2}\right)(\mathrm{NO})(1-\text { pramcyH })\right]^{3+} \\
& \text { trans }-\left[\mathrm{Ru}\left(\mathrm{OH}_{2}\right)(\mathrm{NO})(1-\text { pramcyH})\right]^{3+} \underset{-\mathrm{e}}{\stackrel{+\mathrm{e} 3 \mathrm{c}}{\rightleftharpoons}} \operatorname{trans}^{-}\left[\mathrm{Ru}\left(\mathrm{H}_{2} \mathrm{O}\right)(\mathrm{NO})(1-\text { pramcyH})\right]^{2+} \\
& \text { trans }-\left[\mathrm{Ru}\left(\mathrm{H}_{2} \mathrm{O}\right)_{2}(1-\text { pramcyH })\right]^{4+} \underset{-\mathrm{e} 4 \mathrm{a}}{\stackrel{+\mathrm{e}}{\rightleftharpoons}} \text { trans- }\left[\mathrm{Ru}\left(\mathrm{H}_{2} \mathrm{O}\right)_{2}(1-\text { pramcyH })\right]^{3+}
\end{aligned}
$$


trans $-\left[\mathrm{Ru}\left(\mathrm{OH}_{2}\right)(\mathrm{NO})(1-\text { pramcyH})\right]^{3+}+\mathrm{H}_{2} \mathrm{O} \rightleftharpoons$ trans $-[\mathrm{Ru}(\mathrm{OH})(\mathrm{NO})(1-\text { pramcyH})]^{2+}+\mathrm{H}_{3} \mathrm{O}^{+} \quad$ pKa ca. 7

trans $-\left[\mathrm{Ru}\left(\mathrm{OH}_{2}\right)(\mathrm{NO})(1-\text { pramcyH})\right]^{4+}+\mathrm{H}_{2} \mathrm{O} \rightleftharpoons$ trans $-[\mathrm{Ru}(\mathrm{OH})(\mathrm{NO})(1-\text { pramcyH})]^{3+}+\mathrm{H}_{3} \mathrm{O}^{+} \quad$ pKa ca. 2

reported value, at $\mathrm{pH} 1$, of $-100 \mathrm{mV}^{48}$ and of $-155 \mathrm{mV}$ for trans- $\left[\mathrm{Ru}\left(\mathrm{H}_{2} \mathrm{O}\right)_{2}(\text { cyclam })\right]^{2+}{ }^{61}$ The possibility that the $\mathrm{Ep}_{3 \mathrm{c}}$ process may involve five electrons and result in reduction of NO to amine, as reported for some cases, ${ }^{62-64}$ is under investigation in our laboratories.

From plots of $\mathrm{Ep}_{2 \mathrm{c}}$ versus $\mathrm{pH}$ it was possible to estimate the equilibrium constants for the reactions represented in equations 8 and 9 .

The estimated $\mathrm{pK}_{\mathrm{a}}$ value of 2 for the trans-[Ru(NO) $\left(\mathrm{OH}_{2}\right)(1$-pramcyH $\left.)\right]^{4+}$ species is close to those of trans$\left[\mathrm{Ru}(\mathrm{NO})\left(\mathrm{OH}_{2}\right)(\mathrm{cyclam})\right]^{3+}$ and trans-[Ru(NO) $\left(\mathrm{OH}_{2}\right)$ $\left.\left(\mathrm{NH}_{3}\right)_{4}\right]^{3+}$ species, $\mathrm{pK}_{\mathrm{a}}=3.1 .^{25,42}$ As in the case of the latter two complexes and others, such as trans-[Ru(salen) (NO) $\left.\left(\mathrm{OH}_{2}\right)\right]^{+}$with a $\mathrm{pK}_{\mathrm{a}}$ of $4,{ }^{40}$ it indicates a strong $\mathrm{Ru}^{\mathrm{III}}$ character.

\section{Spectroelectrochemistry}

The infrared and UV-Vis spectral changes observed for trans-[Ru(NO)Cl(1-pramcyH) $]\left(\mathrm{PF}_{6}\right)_{3}$ when it is submitted to a controlled potential electrolysis at $-500 \mathrm{mV} v s$. $\mathrm{Ag} / \mathrm{AgCl}$ in acetonitrile $\left(\mu=0.1 \mathrm{~mol} \mathrm{~L}^{-1}\right.$ tba $\left.\left(\mathrm{PF}_{6}\right)\right)$ are shown in Figures 5 and 6. We were unable to avoid some solvent evaporation during the experiments, which may explain the absence of clean isosbestic points. The intensity of the $v(\mathrm{NO})$ band at $1864 \mathrm{~cm}^{-1}$ decreases, while a new peak appears at $1810 \mathrm{~cm}^{-1}$, the intensity of which increases. These changes are consistent with the reduction of the nitrosyl ligand, forming trans-[Ru(NO) $\mathrm{Cl}(1$-pramcyH $)]^{2+}$, and are similar to results previously described in the literature. ${ }^{18,25}$

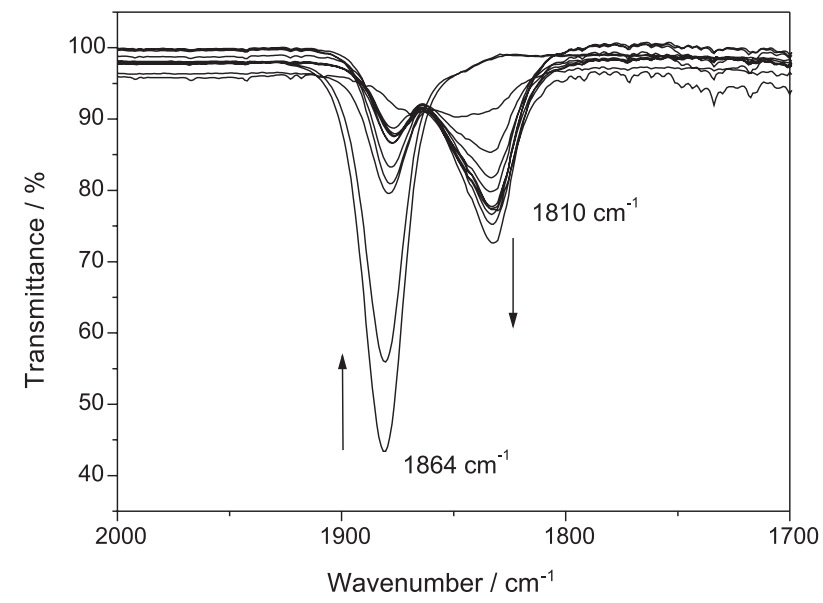

Figure 5. Infrared spectral changes during controlled potential electrolysis at $-500 \mathrm{mV}(v s . \mathrm{Ag} / \mathrm{AgCl})$ of trans-[Ru(NO)Cl(1-pramcyH $)]\left(\mathrm{PF}_{6}\right)_{3}$ in a $2.1 \times 10^{-2} \mathrm{~mol} \mathrm{~L}^{-1}$ acetonitrile solution containing $0.1 \mathrm{~mol} \mathrm{~L}^{-1}$ tba $\left(\mathrm{PF}_{6}\right)$ at $25^{\circ} \mathrm{C}$. Time intervals between spectra: $10 \mathrm{~min}$.

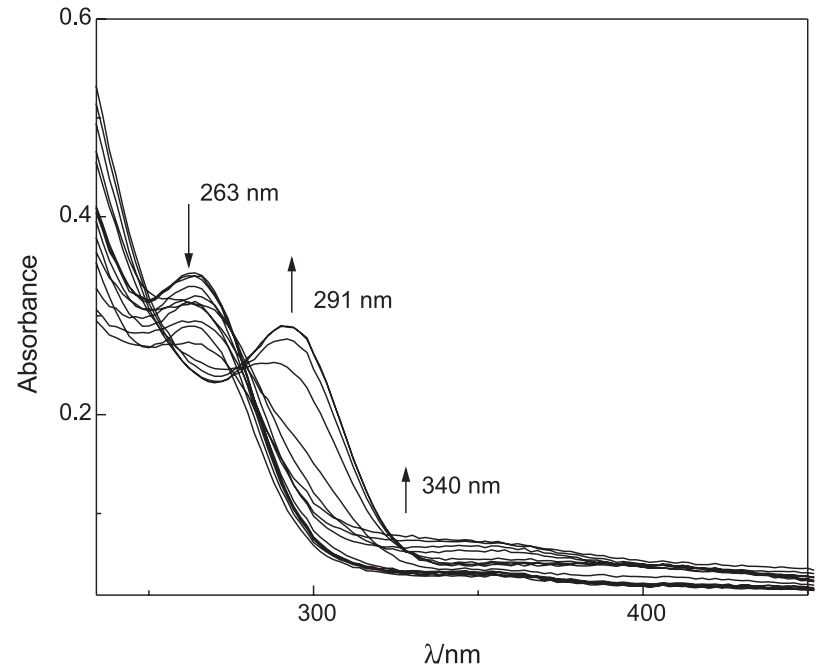

Figure 6. UV-Vis spectral changes during controlled potential electrolysis at $-500 \mathrm{mV}$ (vs. $\mathrm{Ag} / \mathrm{AgCl}$ ) of a $2.1 \times 10^{-2} \mathrm{~mol} \mathrm{~L}^{-1}$ acetonitrile solution of trans-[Ru(NO)Cl(1-pramcyH) $]\left(\mathrm{PF}_{6}\right)_{3}$ containing $0.1 \mathrm{~mol} \mathrm{~L}^{-1}$ tba $\left(\mathrm{PF}_{6}\right)$ at $25^{\circ} \mathrm{C}$. Time intervals between spectra: $10 \mathrm{~min}$.

However, it has been reported that the spectra of reduced froms of nitrosyl complexes show the $v(\mathrm{NO})$ peak at much lower wavenumbers. ${ }^{65,66}$

The electronic absorption spectral changes observed for trans- $[\mathrm{Ru}(\mathrm{NO}) \mathrm{Cl}(1-$ pramcyH $)]\left(\mathrm{PF}_{6}\right)_{3}$ consist of an absorbance decrease at $263 \mathrm{~nm}$ with a concomitant increase at $291 \mathrm{~nm}$. The final electronic absorption spectrum is assigned to the trans-[Ru(NO)Cl(1-pramcyH) $]^{2+}$ complex. Likewise, the UV-Vis monitoring of the non-exhaustively controlled potential electrolysis of trans-[RuCl(cyclam) $(\mathrm{NO})]\left(\mathrm{PF}_{6}\right)_{2}$, carried out in the same conditions to promote reduction of $\mathrm{NO}^{+}$to $\mathrm{NO}$, shows absorbance decrease at $254 \mathrm{~nm}$ with concomitant increase at $298 \mathrm{~nm}$, which in acetonitrile and under a reductive potential should denote coordinated $\mathrm{NO}^{0}$.

\section{Photochemical studies}

Irradiation of trans-[Ru(NO)Cl(1-pramcyH) $]\left(\mathrm{PF}_{6}\right)_{3}$ in a deaerated $0.1 \mathrm{~mol} \mathrm{~L}^{-1} \mathrm{HPF}_{6}$ solution with light of $\lambda=334 \mathrm{~nm}$ results in the decrease in intensity of the $v(\mathrm{NO})$ band at $1875 \mathrm{~cm}^{-1}$ (Figure 7). This decrease undoubtedly suggests the photochemical labilization of NO (equation 10). Similar changes in the infrared spectrum had already been observed with $10^{-2} \mathrm{~mol} \mathrm{~L}^{-1}$ trans $-[\mathrm{RuCl}(\mathrm{NO})(\text { cyclam})]^{2+}$ and trans-[RuCl$\left.\left([15] \mathrm{aneN}_{4}\right) \mathrm{NO}\right]^{2+}$ solutions at $\mathrm{pH} 7,{ }^{17}$ and with trans-[RuCl(NO)(cyclam) $]]^{2+}$ in a xerogel matrix. ${ }^{16}$ Addition of silver nitrate solution to the photolyzed solution did not 


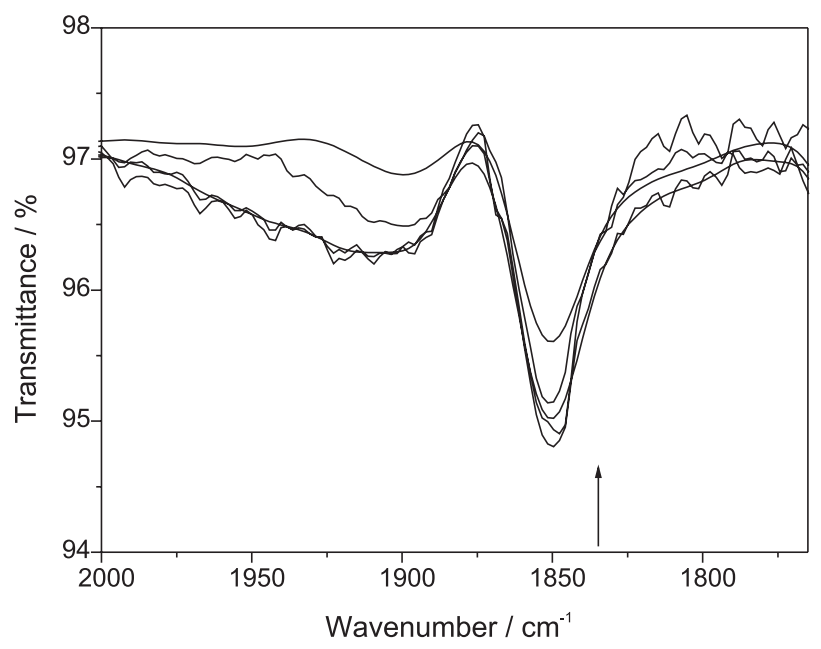

Figure 7. Infrared spectral changes during photolysis $(\lambda=334 \mathrm{~nm})$ of a $1 \times 10^{-2} \mathrm{~mol} \mathrm{~L}^{-1}$ solution of trans-[Ru(NO)Cl(1-pramcyH)$]\left(\mathrm{PF}_{6}\right)_{3}$ in $0.1 \mathrm{~mol} \mathrm{~L}^{-1} \mathrm{HPF}_{6}$ at $25^{\circ} \mathrm{C}$. Total photolysis time: $3 \mathrm{~h}$.

evidence formation of $\mathrm{AgCl}$, indicating that chloride is not labilized as far as this assay is considered.

The UV-Vis spectral changes during photolysis of trans-[Ru(NO)Cl(1-pramcyH) $]\left(\mathrm{PF}_{6}\right)_{3}$ with $334 \mathrm{~nm}$ light at $\mathrm{pH} 1$ are shown in Figure 8. There is a broad absorption increase in the $300-390 \mathrm{~nm}$ region, which is consistent with the formation of the $\mathrm{Ru}^{\mathrm{III}}$ aquo complex photoproduct, trans- $\left[\mathrm{Ru}\left(\mathrm{OH}_{2}\right) \mathrm{Cl}(1-\text { pramcyH})\right]^{3+}$ (equation 10), as observed for trans-[RuCl(NO)(cyclam) $]\left(\mathrm{PF}_{6}\right)_{2}{ }^{27}$ and other ruthenium ammine nitrosyl complexes. ${ }^{16,17}$ At this $\mathrm{pH}$, trans- $\left[\mathrm{Ru}\left(\mathrm{OH}_{2}\right) \mathrm{Cl}(1-\text { pramcyH})\right]^{3+}$ has an absorption band

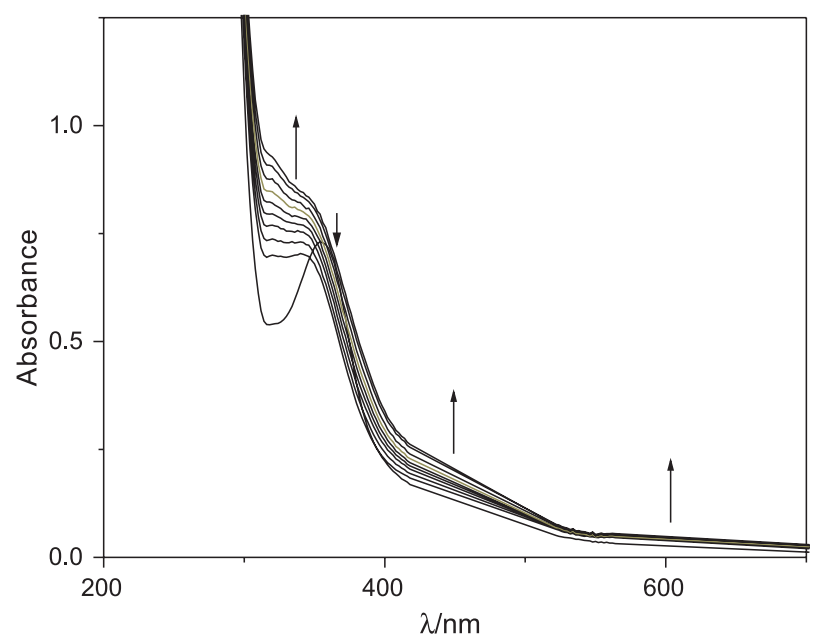

Figure 8. UV-Vis spectral changes during photolysis $(\lambda=334 \mathrm{~nm})$ of a $2.6 \times 10^{-2} \mathrm{~mol} \mathrm{~L}^{-1}$ solution of trans-[Ru(NO)Cl(1-pramcyH)]( $\left.\mathrm{PF}_{6}\right)_{3}$ in $\mathrm{CF}_{3} \mathrm{SO}_{3} \mathrm{H}^{-} \mathrm{CF}_{3} \mathrm{SO}_{3} \mathrm{Na}\left(\mu=0.1 \mathrm{~mol} \mathrm{~L}^{-1}, \mathrm{pH} 1\right)$ at $25^{\circ} \mathrm{C}$. Total photolysis time: $3 \mathrm{~h}$. at $\lambda_{\max } / \mathrm{nm}=356\left(\varepsilon /\left(\mathrm{dm}^{3} \mathrm{~mol}^{-1} \mathrm{~cm}^{-1}\right)=2900\right)$. At pH 4.75 or 4.90 , the photoproduct is mainly trans- $[\mathrm{Ru}(\mathrm{OH}) \mathrm{Cl}(1-$ pramcyH $)]^{2+}$, which absorbs at $\lambda_{\text {max }}=356(\varepsilon=830)$. At $\mathrm{pH} 7.4$, trans- $\left[\mathrm{Ru}^{\mathrm{III}}(\mathrm{OH}) \mathrm{Cl}(1 \text {-pramcy })\right]^{+}$absorbs at $\lambda_{\max }=356(\varepsilon=2900)$.

The photoproducts quantum yields for the photolysis of trans-[Ru(NO)Cl(1-pramcyH) $]\left(\mathrm{PF}_{6}\right)_{3}$ are shown in Table 1.

Table 1. Quantum yield values for NO photoaquation from trans-[Ru(NO) $\mathrm{Cl}(1$-pramcyH $)]\left(\mathrm{PF}_{6}\right)_{3}$ at different $\mathrm{pH}$ values and irradiation wavelengths

\begin{tabular}{lcc}
\hline $\mathrm{pH}$ & $\lambda_{\text {irr }} / \mathrm{nm}$ & $\phi_{\mathrm{NO}}{ }^{\mathrm{a}}$ \\
\hline 1.00 & 313 & $0.009( \pm 0.001)$ \\
1.00 & 334 & $0.008( \pm 0.001)$ \\
1.00 & 370 & $<0.0010$ \\
4.75 & 313 & $0.010( \pm 0.002)$ \\
4.75 & 334 & $0.009( \pm 0.001)$ \\
4.75 & 370 & $<0.001$ \\
4.90 & 313 & $0.030( \pm 0.002)$ \\
4.90 & 334 & $0.011( \pm 0.001)$ \\
4.90 & 370 & $<0.002$ \\
7.40 & 313 & $0.10( \pm 0.002)$ \\
7.40 & 334 & $0.09( \pm 0.01)$ \\
7.40 & 370 & $<0.003$ \\
\hline
\end{tabular}

${ }^{a}$ Average values of three determinations. $\mathrm{pH} 1$ in a $\mathrm{CF}_{3} \mathrm{SO}_{3} \mathrm{H}_{/} \mathrm{CF}_{3} \mathrm{SO}_{3} \mathrm{Na}$ $\left(\mu=0.1 \mathrm{~mol} \mathrm{~L}^{-1} ; \mathrm{pH} 1\right) ; \mathrm{pH} 4.75$ and $4.90\left(0.01 \mathrm{~mol} \mathrm{~L}^{-1}\right.$ acetate buffer $)$; pH 7.4 in $0.1 \mathrm{~mol} \mathrm{~L}^{-1}$ phosphate buffer.

The quantum yields pattern for the photolysis of trans-[Ru(NO)Cl(1-pramcyH) $]\left(\mathrm{PF}_{6}\right)_{3}$ is similar to those of other nitrosyl ruthenium(am(m)ine) complexes. ${ }^{14,17,18,46,67}$ The quantum yields decrease as $\mathrm{pH}$ decreases and as the irradiation wavelength increases, being noticeable only at $\lambda_{\text {irr }}<370 \mathrm{~nm}$. The larger quantum yields achieved at larger $\mathrm{pH}$ values can be explained, as in the case of the analogous trans-[Ru(NO) $\left.\left(\mathrm{NH}_{3}\right)_{4}(\mathrm{py}-\mathrm{X})\right]^{3+}$ complexes, ${ }^{46}$ as follows. The trans-[Ru(NO)Cl(1-pramcyH) $]\left(\mathrm{PF}_{6}\right)_{3}$ complex has 3 $\mathrm{pK}_{\mathrm{a}}$ values, and as the $\mathrm{pH}$ increases, in addition to other species a larger fraction of the product is in the hydroxo form. Different species are not necessarily expected to have the same quantum yields. Also, the hydroxo complex is likely to be much less reactive toward the back reaction with NO than the corresponding aquo product, and, thus, has larger quantum yields. As a matter of fact, the increase in quantum yield with larger $\mathrm{pH}$ is also consistent with the synthesis of trans-[Ru(NO)Cl(1-pramcyH) $]^{3+}$ (see Experimental).

$$
\text { trans-[RuCl(NO)(1-pramcyH) }]^{3+} \underset{\mathrm{H}_{2} \mathrm{O}, \mathrm{H}^{+}}{\stackrel{\mathrm{h} v}{\longrightarrow}} \operatorname{trans}-\left[\mathrm{RuCl}\left(\mathrm{OH}_{2}\right)(1-\text { pramcyH})\right]^{3+}+\mathrm{NO}
$$




\section{Conclusions}

The procedures described here result in the successful synthesis of a ruthenium nitrosyl complex with the substituted 1-(3-propylammonium)cyclam, trans-[Ru(NO) $\mathrm{Cl}$ (1-pramcyH)] $\left(\mathrm{PF}_{6}\right)_{3}$. Unlike 1-carboxypropyl, which results in a fac configuration for the nitrosyl complex, the aminopropyl results in the thermodynamically expected trans arrangement. This amine functionalized complex can be linked to a peptide, or an antibody, for selective biological activity. It can also be bound to a support in a device, such as a stent, to form a drug eluting stent. The behavior of trans-[Ru(NO)Cl(1-pramcyH) $]^{3+}$, which contains a substituted cyclam, parallels that of the cyclam analog, suggesting that these complexes could maintain their properties when linked to a biomolecule. Electrochemical and photochemical experiments suggest the labilization of NO. Like other ruthenium am(m)mine nitrosyl complexes, such as trans-[Ru(NO) $\left.\left(\mathrm{NH}_{3}\right)_{4}(\mathrm{py}-\mathrm{X})\right]^{\mathrm{n}+}$ and trans- $[\mathrm{RuCl}(\mathrm{NO})(\mathrm{cyclam})]\left(\mathrm{PF}_{6}\right)_{2}$, trans-[Ru(NO) $\mathrm{Cl}(1$-pramcyH $)]\left(\mathrm{PF}_{6}\right)_{3}$ is attractive for potential biological applications because it is stable, water-soluble, and can deliver NO upon activation by reduction at a biologically accessible potential and/or by irradiation with light. Current research in this lab is directed toward these goals for potential applications of the complexes as NO donors.

\section{Supplementary Information}

${ }^{1} \mathrm{H}$ NMR, ${ }^{13} \mathrm{C}$ NMR and electronic absorption spectra, as well as cyclic voltammograms recorded for trans-[Ru(NO) $\mathrm{Cl}(1$-pramcyH $)]\left(\mathrm{PF}_{6}\right)_{3}$, are available free of charge at http://jbcs.sbq.org.br, as a pdf file.

\section{Acknowledgments}

The authors thank the Brazilian agencies FAPESP, CNPq and CAPES for financial support.

\section{References}

1. Ignarro; L. J.; Nitric Oxide: Biology and Pathobiology, $1^{\text {st }}$ ed., Academic Press: San Diego, 2000.

2. Ford, P. C.; Fernandez, B. O.; Lim, M. D.; Chem. Rev. 2005, 105, 2439.

3. Paolocci, N.; Jackson, M. I.; Lopez, B. E.; Miranda, K.; Tocchetti, C. G.; Wink, D. A.; Hobbs, A. J.; Fukuto, J. M.; Pharmacol. Ther. 2007, 113, 442.

4. Rose, M. J.; Mascharak, P. K.; Coord. Chem. Rev. 2008, 252, 2093
5. Miranda, K. M.; Coord. Chem. Rev. 2005, 249, 433.

6. Wink, D. A.; Grisham, M. B.; Miles, A. M.; Nims, R. W.; Krishna, M. C.; Pacelli, R.; Teague, D.; Poore, C. M. B.; Cook. J. A.; Ford, P. C.; Methods Enzymol. 1996, 268, 120.

7. Eroy-Reveles, A. A.; Leung, Y. ;Mascharak, P. K.; J. Am. Chem. Soc. 2006, 128, 7166.

8. Hrabie, J. A.; Keefer, L. K.; Chem. Rev. 2002, 102, 1135.

9. Hayton, T. W.; Legzdins, P.; Sharp, W. B.; Chem. Rev. 2002, 102, 935.

10. Richter-Addo, G. B.; Legzdins, P.; Burstyn, J.; Chem. Rev. 2002, 102, 857.

11. Ford, P. C.; Lorkovic, I. M.; Chem. Rev. 2002, 102, 993.

12. Wang, P. G.; Xian, M.; Tang, X. P.; Wu, X. J.; Wen, Z.; Cai, T. W.; Janczuk, A. J.; Chem. Rev. 2002, 102, 1091.

13. Ostrowski, A. D.; Deakin, S.; J.; Azhar, B.; M.; Miller T. W.; Franco, N.; Cherney, M. M.; Lee, A. J.; Burstyn, J. N.; Fukuto, J. M.; Megson, I. L.; Ford, P. C.; J. Med. Chem. 2010, 53, 715.

14. Tfouni, E.; Krieger, M.; McGarvey, B. R.; Franco, D. W.; Coord. Chem. Rev. 2003, 236, 57.

15. Zanichelli, P. G.; Estrela, H. F. G.; Spadari-Bratfisch, R. C.; Grassi-Kassisse, D. M.; Franco, D. W.; Nitric Oxide-Biol. Chem. 2007, 16, 189.

16. Ferreira, K. Q.; Schneider, J. F.; Nascente, P. A. P.; Rodrigues, U. P. ; Tfouni, E.; J. Colloid Interface Sci. 2006, 300, 543.

17. Oliveira, F. D.; Ferreira, K. Q.; Bonaventura, D.; Bendhack, L. M.; Tedesco, A. C.; Machado, S. D.; Tfouni, E.; da Silva, R. S.; J. Inorg. Biochem. 2007, 101, 313.

18. Tfouni, E.; Ferreira, K. Q.; Doro, F. G.; da Silva, R. S.; da Rocha, Z. N.; Coord. Chem. Rev. 2005, 249, 405.

19. Doro, F. G.; Castellano, E. E.; Moraes, L. A. B.; Eberlin, M. N.; Tfouni, E.; Inorg. Chem. 2008, 47, 4118.

20. Doro, F. G.; Rodrigues, U. P.; Tfouni, E.; J. Colloid Interface Sci. 2007, 307, 405.

21. da Rocha, Z. N.; Marchesi, M. S. P.; Molin, J. C.; Lunardi, C. N.; Miranda, K. M.; Bendhack, L. M.; Ford, P. C.; da Silva, R. S.; Dalton Trans. 2008, 4282.

22. Ford, P. C.; Wecksler, S.; Coord. Chem. Rev. 2005, 249, 1382.

23. Holanda, A. K. M.; Pontes, D. L.; Diogenes, I. C. N.; Moreira, I. S.; Lopes, L. G. F.; Transition Met. Chem. 2004, 29, 430.

24. Holanda, A. K. M.; da Silva, F. O. N.; Carvalho, I. M. M.; Batista, A. A.; Ellena, J.; Castellano, E. E.; Moreira, I. S.; Lopes, L. G. F.; Polyhedron 2007, 26, 4653.

25. Lang, D. R.; Davis, J. A.; Lopes, L. G. F.; Ferro, A. A.; Vasconcellos, L. C. G.; Franco, D. W.; Tfouni, E.; Wieraszko, A.; Clarke, M. J.; Inorg. Chem. 2000, 39, 2294.

26. Lopes, L. G. F.; Sousa, E. H. S.; Miranda, J. C. V.; Oliveira, C. P.; Carvalho, I. M. M.; Batista, A. A.; Ellena, J.; Castellano, E. E.; Nascimento, O. R.; Moreira, I. S.; J. Chem. Soc., Dalton Trans. 2002, 1903.

27. Lopes, L. M. F.; Garcia, A. R.; Fidalgo, A.; Ilharco, L. M.; Langmuir 2009, 25, 10243. 
28. Silva, F. O. N.; Araujo, S. X. B.; Holanda, A. K. M.; Meyer, E.; Sales, F. A. M.; Diogenes, H. C. N.; Carvalho, I. M. M.; Moreira, I. S.; Lopes, L. G. F.; Eur. J. Inorg. Chem. 2006, 2020.

29. Butler, A. R.; Megson, I. L.; Chem. Rev. 2002, 102, 1155.

30. Gomes, A. J.; Barbougli, P. A.; Espreafico, E. M.; Tfouni, E.; J. Inorg. Biochem. 2008, 102, 757.

31. Cicillini, S. A.; Prazias, A. C.; Tedesco, A. C.; Serra, O. A.; da Silva, R. S.; Nitric Oxide-Biol. Chem. 2008, 19, S67.

32. Madhani, M.; Patra, A. K.; Miller, T. W.; Eroy-Reveles, A. A.; Hobbs, A. J.; Fukuto, J. M.; Mascharak, P. K.; J. Med. Chem. 2006, 49, 7325 .

33. de Barros, B. F.; Toledo, J. C.; Franco, D. W.; Tfouni, E.; Krieger, M. H.; Nitric Oxide-Biol. Chem. 2002, 7, 50.

34. Marcondes, F. G.; Ferro, A. A.; Souza-Torsoni, A.; Sumitani, M.; Clarke, M. J.; Franco, D. W.; Tfouni, E.; Krieger, M. H.; Life Sci. 2002, 70, 2735.

35. Silva, J. J. J.; Osakabe, A. L.; Pavanelli, W. R.; Silva, J. S.; Franco, D. W.; Br. J. Pharmacol. 2007, 152, 112.

36. Silva, J. J. N.; Pavanelli, W. R.; Gutierrez, F. R. S.; Lima, F. C. A.; da Silva, A. B. F.; Silva, J. S.; Franco, D. W.; J. Med. Chem. 2008, 51, 4104.

37. Pestana, C. R.; Phelippin, D. P. S.; Polizello, A. C. M.; Dorta, D. J.; Uyemura, S. A.; Santos, A. C.; Doro, F. G.; Rodrigues, F. P.; Tfouni, E.; Curti, C.; Nitric Oxide-Biol. Chem. 2009, 20, 24.

38. Bonaventura, D.; Lunardi, C. N.; Rodrigues, G. J.; Neto, M. A.; de Lima, R. G.; da Silva, R. S.; Bendhack, L. M.; Basic Clin. Pharmacol. Toxicol. 2008, 102, 38.

39. Keefer, L. K.; Nat. Mater. 2003, 2, 357.

40. Bordini, J.; Novaes, D. O.; Borissevitch, I. E.; Owens, B. T.; Ford, P. C.; Tfouni, E.; Inorg. Chim. Acta 2008, 361, 2252.

41. Tfouni, E.; Doro, F. G.; Gomes, A. J.; Silva, R. S.; Metzker, G.; Benini, P. G. Z.; Franco D. W.; Coord. Chem. Rev. 2010, 254, 355.

42. Bezerra, C. W. B.; da Silva, S. C.; Gambardella, M. T. P.; Santos, R. H. A.; Plicas, L. M. A.; Tfouni, E.; Franco, D. W.; Inorg. Chem. 1999, 38, 5660.

43. Gomes, M. G.; Davanzo, C. U.; Silva, S. C.; Lopes, L. G. F.; Santos, P. S.; Franco, D. W.; J. Chem. Soc., Dalton Trans. 1998, 601.

44. Bordini, J.; Ford, P. C.; Tfouni, E.; Chem. Commun. 2005, 4169.

45. Calandreli, I.; Oliveira, F. D.; Liang, G. G.; da Rocha, Z. N.; Tfouni, E.; Inorg. Chem. Commun. 2009, 591.

46. Carlos, R. M.; Ferro, A. A.; Silva, H. A. S.; Gomes, M. G.; Borges, S. S. S.; Ford, P. C.; Tfouni, E.; Franco, D. W.; Inorg. Chim. Acta 2004, 357, 1381.
47. Ferreira, K. Q.; Santos, F. G.; da Rocha, Z. N.; Guaratini, T.; da Silva, R. S.; Tfouni, E.; Inorg. Chem. Commun. 2004, 7, 204.

48. Ferreira, K. Q.; Doro, F. G.; Tfouni, E.; Inorg. Chim. Acta 2003, 355, 205.

49. Sauaia, M. G.; Oliveira, F. D. S.; de Lima, R. G.; Cacciari, A. D. L.; Tfouni, E.; da Silva, R. S.; Inorg. Chem. Commun. 2005, $8,347$.

50. De Candia, A. G.; Marcolongo, J. P.; Slep, L. D., Polyhedron 2007, 26, 4719.

51. Che, C. M.; Tang, W. T.; Mak, T. C. W.; J. Chem. Soc., Dalton Trans. 1988, 2879.

52. Vogel, A. I. Química Orgânica Qualitativa, 5a. ed., Ao Livro Técnico: Rio de Janeiro, Brasil, 1980.

53. Calvert, J. G.; Pitts, J. N.; Photochemistry, $1^{\text {st }}$ ed., Willey: New York, 1966.

54. da Rocha, Z. N.; Ferreira, K. Q.; Silva, M.; de Oliveira, E. C.; Chiericato, G.; Tfouni, E.; Inorg. Chem. 2001, 40, 5385.

55. Schiegg, A.; Kaden, T. A.; Helv. Chim. Acta. 1990, 73, 716.

56. Pallavicini, P. S.; Perotti, A.; Poggi, A.; Seghi, B.; Fabbrizzi, L.; J. Am. Chem. Soc. 1987, 109, 5139.

57. Richter-Addo, G. B.; Legzdins, P.; Metal Nitrosyls, $1^{\text {st }}$ ed., Oxford University Press: New York, 1992.

58. Enemark, J. H.; Feltham, R. D.; Coord. Chem. Rev. 1974, 13, 339.

59. da Silva, R. S.; Gambardella, M. T. P.; Santos, R. H. A.; Mann, B. E.; Tfouni, E.; Inorg. Chim. Acta 1996, 245, 215.

60. McGarvey, B. R.; Batista, N. C.; Bezerra, C. W. B.; Schultz, M. S.; Franco, D. W.; Inorg. Chem. 1998, 37, 2865.

61. Walker, D. D.; Taube, H.; Inorg. Chem. 1981, 20, 2828.

62. Sauaia, M. G.; da Silva, R. S.; Trans. Met. Chem. 2003, $28,254$.

63. Thompson, M. S.; Meyer, T. J.; J. Am. Chem. Soc. 1981, 103, 5577.

64. Murphy, W. R.; Takeuchi, K.; Barley, M. H.; Meyer, T. J.; Inorg. Chem. 1986, 25, 1041.

65. Baumann, F.; Kaim, W.; Baraldo, L. M.; Slep, L. D.; Olabe, J. A.; Fiedler, J.; Inorg. Chim. Acta 1999, 285, 129.

66. Kurtikyan, T.S.; Hovhannysian, A.A..; Hakobyan, M.E.; Patterson, J.C.; Irtskii, A.; Ford, P.C.; J. Am. Chem. Soc. 2007, $129,3576$.

67. Tfouni, E.; Coord. Chem. Rev. 2000, 196, 281.

Received: October 27, 2009

Web Release Date: April 29, 2010

FAPESP helped in meeting the publication costs of this article. 


\section{Chemical and Photochemical Properties of a Ruthenium Nitrosyl Complex with the $N$-Monosubstituted Cyclam 1-(3-Propylammonium)-1,4,8,11- tetraazacyclotetradecane}

\section{Kleber Q. Ferreira ${ }^{a, b}$ and Elia Tfouni ${ }^{*, a}$}

${ }^{a}$ Departamento de Química, Faculdade de Filosofia, Ciências e Letras de Ribeirão Preto, Universidade de São Paulo - USP, Av. Bandeirantes, 3900, 14040-901 Ribeirão Preto-SP, Brazil

${ }^{b}$ Departamento de Química Geral e Inorgânica, Instituto de Química, Universidade Federal da Bahia, Rua Barão de Jeremoabo, s/n, Campus Universitário de Ondina,

40170-115 Salvador-BA, Brazil

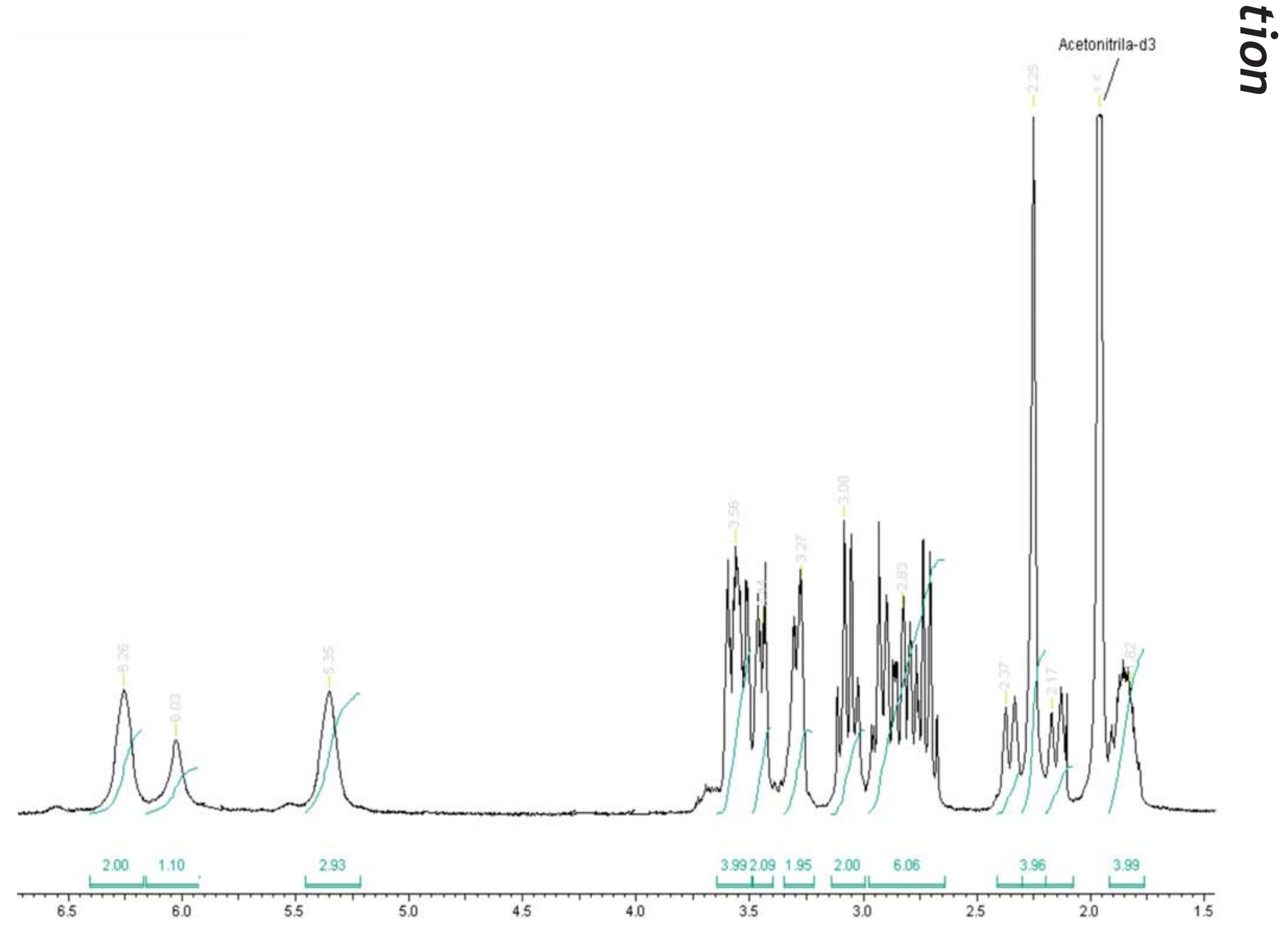

Figure S1. ${ }^{1} \mathrm{H}$ NMR spectrum $(400.13 \mathrm{MHz})$ of trans-[Ru(NO)Cl(1-pramcyH) $]\left(\mathrm{PF}_{6}\right)_{3}$ in acetonitrile- $d_{3}$. 


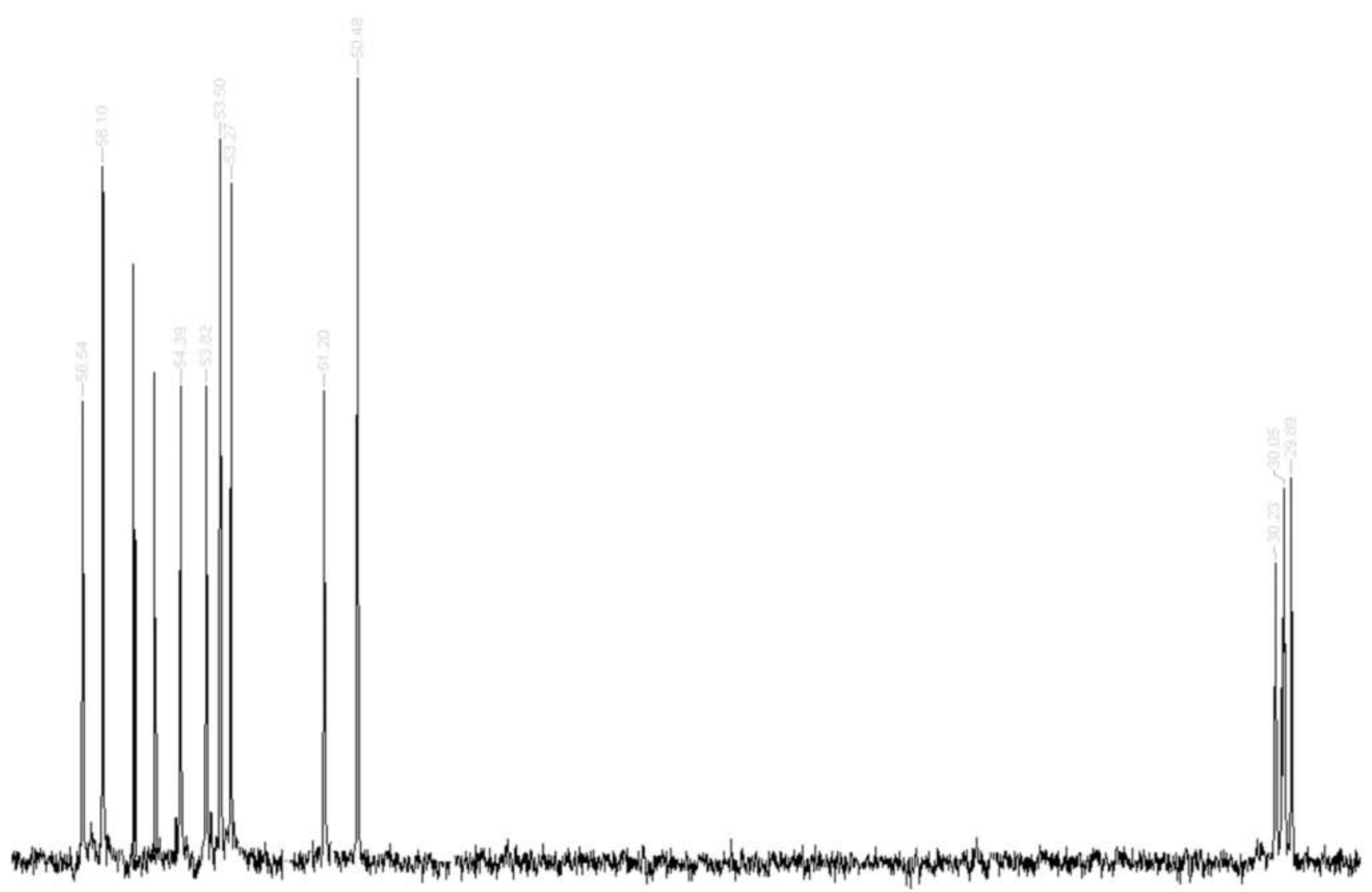

Figure S2. ${ }^{13} \mathrm{C}\left\{{ }^{1} \mathrm{H}\right\}$ NMR spectrum $(100.61 \mathrm{MHz})$ of trans- $[\mathrm{Ru}(\mathrm{NO}) \mathrm{Cl}(1-$ pramcyH$)]\left(\mathrm{PF}_{6}\right)_{3}$ in acetonitrile- $d_{3}$.

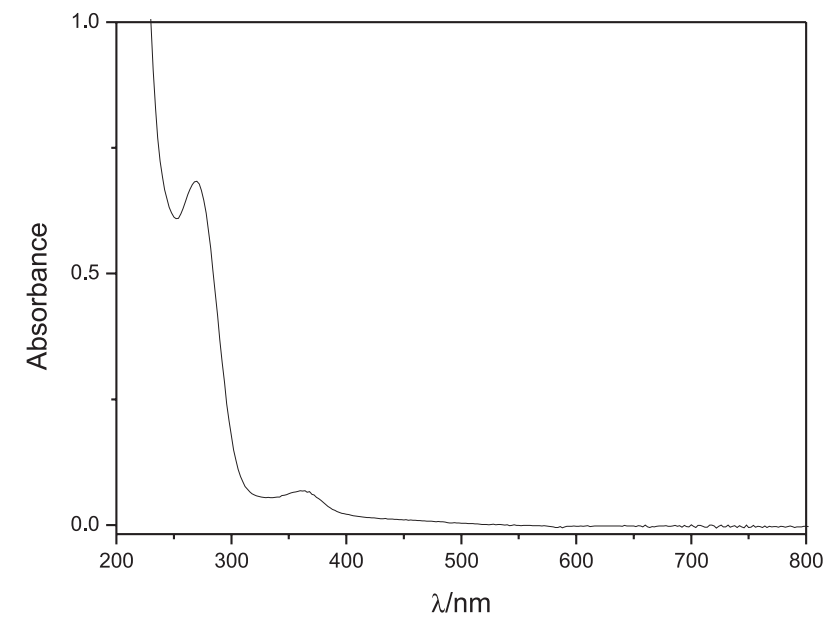

Figure S3. Electronic absorption spectrum of a $3.0 \times 10^{-4} \mathrm{~mol} \mathrm{~L}^{-1}$ aqueous solution $(\mathrm{pH} 1)$ of trans-[Ru(NO)Cl(1-pramcyH) $]^{3+}$.

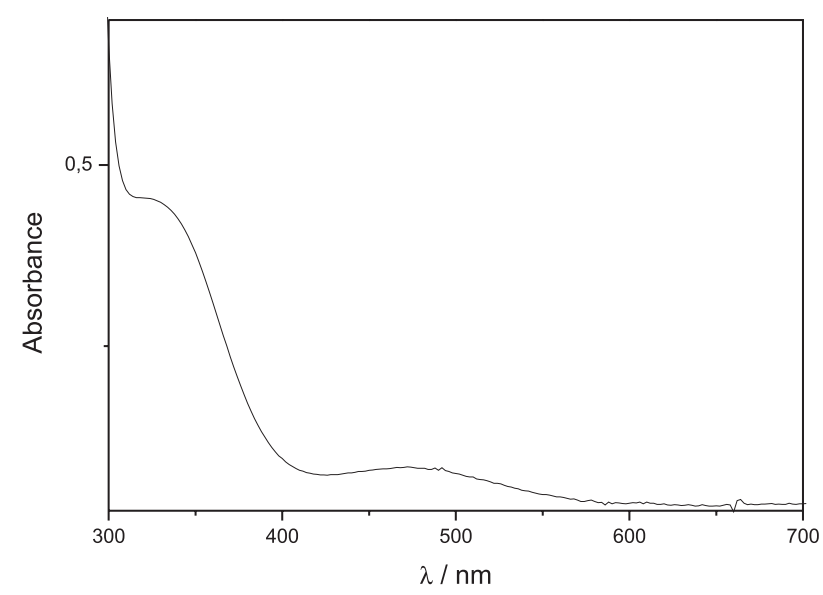

Figure S4. Electronic absorption spectrum of a $1.8 \times 10^{-3} \mathrm{~mol} \mathrm{~L}^{-1}$ aqueous solution $(\mathrm{pH} 1)$ of trans-[Ru(NO)Cl(1-pramcyH) $]^{3+}$. 


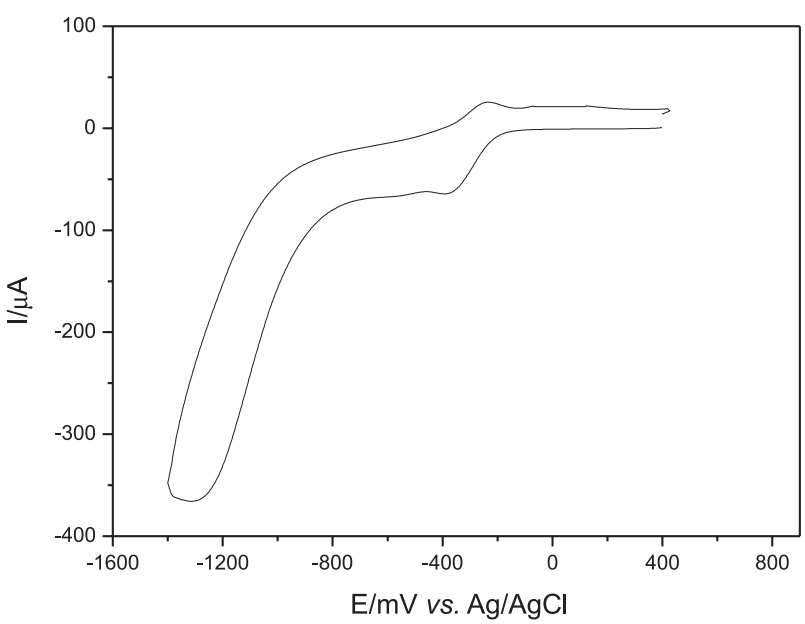

Figure S5. Cyclic voltammogram of a $7 \times 10^{-3} \mathrm{~mol} \mathrm{~L}^{-1}$ solution of trans$[\mathrm{Ru}(\mathrm{NO}) \mathrm{Cl}(1$-pramcyH $)]\left(\mathrm{PF}_{6}\right)_{3}$ in acetonitrile $\left[25{ }^{\circ} \mathrm{C} ; 100 \mathrm{mV} \mathrm{s}^{-1}\right.$; $\mu=0.1 \mathrm{~mol} \mathrm{~L}^{-1}$ tba $\left.\left(\mathrm{PF}_{6}\right)\right]$, at $100 \mathrm{mV} \mathrm{s}^{-1}$, with glassy carbon, $\mathrm{Ag} / \mathrm{AgCl}$ and platinum wire as working, reference and auxiliary electrodes, respectively. $\mathrm{T}=25^{\circ} \mathrm{C}$.

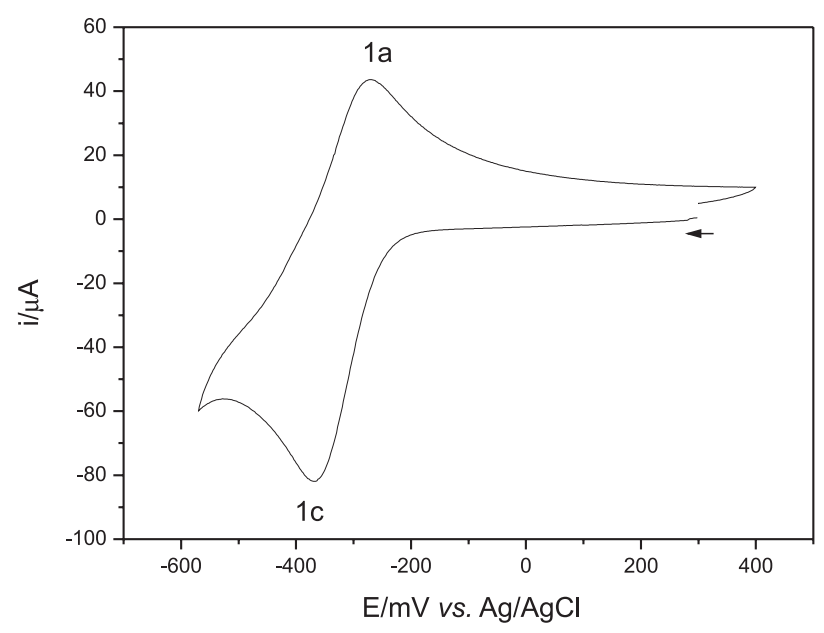

Figure S6. Cyclic voltammogram of a $7 \times 10^{-3} \mathrm{~mol} \mathrm{~L}^{-1}$ solution of trans$[\mathrm{Ru}(\mathrm{NO}) \mathrm{Cl}(1$-pramcyH $)]\left(\mathrm{PF}_{6}\right)_{3}$ in $0.2 \mathrm{~mol} \mathrm{~L}^{-1} \mathrm{LiCl}(\mathrm{pH} 6)$ at $100 \mathrm{mV} \mathrm{s}^{-1}$, with glassy carbon, $\mathrm{Ag} / \mathrm{AgCl}$ and platinum wire as working, reference and auxiliary electrodes, respectively. $\mathrm{T}=25^{\circ} \mathrm{C}$. 